University of Florida Levin College of Law

UF Law Scholarship Repository

UF Law Faculty Publications

Faculty Scholarship

Spring 2013

\title{
The Relevance Games: Congress's Choices for Economic Substance Gamemakers
}

Charlene Luke

University of Florida Levin College of Law, lukec@law.ufl.edu

Follow this and additional works at: http://scholarship.law.ufl.edu/facultypub

Part of the Tax Law Commons

\section{Recommended Citation}

Charlene D. Luke, The Relevance Games: Congress's Choices for Economic Substance Gamemakers, 66 Tax Law. 551 (2013), available at http://scholarship.law.ufl.edu/facultypub/627

This Article is brought to you for free and open access by the Faculty Scholarship at UF Law Scholarship Repository. It has been accepted for inclusion in UF Law Faculty Publications by an authorized administrator of UF Law Scholarship Repository. For more information, please contact outler@law.ufl.edu. 


\title{
The Relevance Games: \\ Congress's Choices for Economic Substance Gamemakers
}

\author{
CHARLENE D. LUKE*
}

\section{ABSTRACT}

Codification of the economic substance doctrine in 2010 ushered in a new phase in the debate regarding the meaning and reach of the doctrine. The main statutory hint as to the intended scope of the codified economic substance doctrine is ambiguous, providing, "The determination of whether the economic substance doctrine is relevant to a transaction shall be made in the same manner as if this subsection had never been enacted." This Article argues that this language should be read in light of the codification history, which stretches back for over ten years before enactment. This history suggests that the relevance provision is primarily about maintaining the precodification balance of decision making between tax agencies and courts. The history also indicates that the provision reflects congressional concurrence in the precodification trajectory of the doctrine, particularly in terms of the types of transactions that were being litigated.

The movement from the common law to codified statute brought with it the potential application of a complex web of authority regarding interactions between tax agencies and courts in their administration, enforcement, and interpretation of the Code. Included in that web is the general ability of the tax agencies to obtain strong deference from the courts as to the agencies' authoritative, reasonable interpretations of textual ambiguities. The economic substance legislative history acknowledges the general interpretive authority of the tax agencies but does not suggest a specific path for reconciling that authority with the requirement that development of the doctrine continue "in the same manner" as under the common law. This Article proposes that

Associate Professor, University of Florida Levin College of Law. I appreciate the thoughts and comments of Karen Burke, Michael Friel, Kristin E. Hickman, Leandra Lederman, William H. Lyons, Grayson M.P. McCouch, Martin J. McMahon Jr., Ajah Mehrotra, William Popkin, James Repetti, Timothy J. Riffle, Sharon Rush, the participants at the Indiana University Maurer School of Law Tax Policy Colloquium, the work of research assistants Justin Bryan, Rachel Espey, Jason Kleiss, and Shay Moorman, and the work of the Georgetown University Law Center student editors for THE TAX LAWYER I thank my home institution, the University of Florida Levin College of Law, for its generous support, including its summer research grant program. Any errors are my own.

The title refers to Suzanne Coluins, The Hunger Games (2010), but, as will be expressed throughout, the economic substance doctrine arena does not feature the arbitrary killing of innocent transactions. 
the various strands in the legislative history can be reconciled by interpreting the relevance provision as adding two directions to tax agencies and courts: (1) the statute does not apply to transactions that are clearly consistent with the form and purpose of claimed tax benefits and (2) the courts have final discretion over whether a specific, litigated transaction ultimately fails the requirements of the economic substance doctrine.

\section{Introduction}

Before the Supreme Court's landmark decision naming the health care mandate a tax, ${ }^{1}$ codification of the economic substance doctrine was among the most controversial tax items contained in the health care legislation. ${ }^{2}$ In broad terms, the economic substance doctrine functions to detect abusive tax shelters and to deny all tax benefits claimed through such shelters. Courts originally developed the economic substance doctrine, with early Supreme Court opinions laying the groundwork and lower courts ultimately structur-

\footnotetext{
'Nat'l Fed'n Indep. Bus. v. Sebelius, 132 S. Ct. 2566, 2593-600 (2012) (holding individual mandate was a constitutional exercise of taxing power). Prior to the Supreme Court's decision on the mandate, numerous articles appeared regarding both the Commerce Clause and tax aspects of the case. See, e.g., Brian Galle, Conditional Taxation and the Constitutionality of Health Care Reform, 120 YALE L.J. OnLINe 27 (2010) (responsibility payment is a constitutional income tax); Edward Kleinbard, Constitutional Kreplach, TAx Notes (TA) 755, 761-62 (Aug. 16, 2010) (healthcare penalty is a constitutional income tax tied to self-insurance); Steven J. Willis \& Nakku Chung, Constitutional Decapitation and Healthcare, 128 TAX Notes (TA) 169 (July 12, 2010) (arguing that penalty is an unconstitutional, unapportioned direct tax-assuming it is a tax).

${ }^{2}$ The health care legislation also included other (labeled) taxes, including an increase in the penalty tax on nonqualifying distributions from certain medical savings accounts, I.R.C. $\$$ $220(\mathrm{f})(4)(\mathrm{A}), 223(\mathrm{f})(4)(\mathrm{A})$; a $0.9 \%$ increase to the Medicare tax on earned income for certain individuals, I.R.C. $\$ 3101$ (b); a new 3.8\% Medicare tax on unearned income for certain individuals, I.R.C. $\$ 1411$; a $10 \%$ excise tax on indoor tanning services, I.R.C. $\$ 5000$ B; a $2.3 \%$ excise tax on the sale of medical devices, I.R.C. $\$ 4191$; and a $40 \%$ excise tax on high-cost employer-sponsored health coverage, I.R.C. $\$ 4980$ I. The Medicare taxes and medical device tax are not scheduled to take effect until 2013, and the 40\% "Cadillac plan" tax takes effect in 2018. For a concise summary of the tax provisions of the healthcare legislation, see $\mathrm{CCH}$ Editorial Staff, 2010 Tax Legislation (2010).

The commentary on the economic substance doctrine is extensive. See, e.g., Joseph Bankman, The Economic Substance Doctrine, 74 S. CAL. L. Rev. 5 (2000); Karen C. Burke, Reframing Economic Substance, 31 VA. TAx Rev. 271 (2011); David P. Hariton, The Frame Game: How Defining the 'Transaction' Decides the Case, 63 TAx Law. 1 (2009) [hereinafter Hariton, Frame Game]; David P. Hariton, Sorting Out the Tangle of Economic Substance, 52 TAX LAw. 235 (1999); Leandra Lederman, W(h)ither Economic Substance?, 95 Iowa L. REv. 389, 395-98 (2010); Charlene Luke, What Would Henry Simons Do?: Using an Ideal to Shape and Explain the Economic Substance Doctrine, 11 Hous. Bus. \& TAX L.J. 108 (2011) [hereinafter Luke, Using an Ideal]; Charlene Luke, Risk, Return, and Objective Economic Substance, 27 VA. TAX REv. 783 (2008) [hereinafter Luke, Risk, Return]; Martin J. McMahon, Jr., Living with the Codified Economic Substance Doctrine, 128 TAx Notes (TA) 731 (Aug. 16, 2010) [hereinafter, McMahon, Jr., Living with Codified]; Martin J. McMahon, Jr., Economic Substance, Purposive Activity, and Corporate Tax Shelters, 94 Tax Notes (TA) 1017 (Feb. 25, 2002).
} 
ing the more formal elements of the doctrine. ${ }^{3}$ For over ten years prior to the healthcare legislation, Congress considered various proposals for codification of the economic substance doctrine, generating in the process a wealth of background material-material that is all the more important because of the context in which the doctrine was enacted. ${ }^{4}$ Instead of being the centerpiece of anti-tax-avoidance legislation, as had been the case in several earlier bills, the economic substance doctrine was codified as a small piece of one of the most expansive, and contentious, legislative packages in recent memory. ${ }^{5} \mathrm{Had}$ Justice Scalia's dissenting position commanded a majority, the economic substance statute would have been among the "minor provisions" struck down as not severable from the main health care legislation. ${ }^{6}$

The uncertainty of the economic substance doctrine's scope contributed significantly to the controversy surrounding Congress's codification efforts. The fear was that tax agencies ${ }^{7}$ would ruthlessly drag innocent transactions into the economic substance doctrine arena. Codification raised the specter that tax agencies would also be able to rig the game by issuing interpretive regulations, making the eventual demise of the selected transactions virtually certain. Such fears seem somewhat disingenuous given the types of transactions that had been tested in the courts under the common law economic substance doctrine. ${ }^{8}$ On the other hand, the statutory text, on its face, does little to address concerns about when a transaction will be tested under the doctrine or when such a test is likely to lead to the rejection of a particular transaction. ${ }^{9}$

The main textual hint as to the scope of the codified doctrine provides the determination of whether the economic substance doctrine is relevant to a

${ }^{3}$ See infra Part II; see also McMahon, Jr., Living with Codified, supra note 2, at 734-36.

${ }^{4}$ See infra Part III.

${ }^{5}$ The Patient Protection and Affordable Care Act, Pub. L. No. 111-148, 124 Stat. 119, amended by the Health Care and Education Reconciliation Act of 2010, Pub. L. No. 111-152, 124 Stat. 1029. The economic substance doctrine was contained in the Health Care and Education Reconciliation Act of 2010. See Health Care and Education Reconciliation Act of 2010, Pub. L. No. 111-152, \$1409, 124 Stat. 1029; see also infra Part III.

${ }^{6}$ Nat'l Fed'n Indep. Bus. v. Sebelius, 132 S. Ct. 2566, 2675 (2012) (Scalia, J., dissenting).

7The term "tax agencies" is used as a shorthand term for the complex group of administrative agencies tasked with oversight and enforcement of the Code. The Service is a bureau within the Department of Treasury (Treasury). Treasury also contains several other tax-related advisers and offices. See David M. Richardson et al., Civil Tax Procedure 5 (2d ed. 2008). The Service handles the majority of the "day-to-day administration of the tax laws," including audits and Tax Court litigation. Id. at 6 . Treasury and the Service generally jointly prepare formal guidance, including regulations. The Service generally issues less formal guidance (e.g., Revenue Rulings, private letter rulings), but even as to such material, collaboration with Treasury is frequent. Id. at 17-25. Tax litigation in all federal courts other than the Tax Court is generally conducted by the Department of Justice, usually in consultation with the Treasury and the Service. Id. at 12.

${ }^{8}$ See Luke, Using an Ideal, supra note 2, at 151-70; Luke, Risk, Return, supra note 2, at 816-31.

${ }^{9}$ See I.R.C. $\$ 7701(\mathbf{0})$. 
transaction shall be made in the same manner as if this subsection had never been enacted. ${ }^{10}$ If taken literally, this language seems to require an impossible task-that the decision about whether to subject a transaction to the new statute be made by asking what would have happened if the statute had never been enacted, even though lack of uniformity in the courts was an important rationale for codification. ${ }^{11}$ This Article argues that this language should be read in light of the extended codification history, ${ }^{12}$ which suggests that the relevance provision ${ }^{13}$ is primarily about maintaining the precodification balance of decision making between tax agencies and courts. The history also indicates that the provision reflects congressional concurrence in the precodification trajectory of the doctrine, particularly in terms of the types of transactions that were being litigated. ${ }^{14}$

The movement from the common law to codified statute brought with it the potential application of a complex web of authority regarding interactions between tax agencies and courts in their administration, enforcement, and interpretation of the Code. Included in this web is the general ability of the tax agencies to obtain strong deference from the courts as to the agen-

${ }^{10}$ I.R.C. $\$ 7701(0)(5)(C)$.

${ }^{11}$ See infra Part III.C.1.

${ }^{12}$ Various other authors have addressed portions of the legislative history, particularly the technical report written by the Joint Committee on Taxation. See, e.g., Tracy A. Kaye, The Regulation of Corporate Tax Shelters in The United States, 58 AM. J. Comp. Law. 585, 600-04 (2010); McMahon Jr., Living with Codified, supra note 2; Bret Wells, Economic Substance Doctrine: How Codification Changes Decided Cases, 10 Fla. TAX REv. 411 (2010). This Article draws from a broader array of material than other economic substance legislative history discussions have done.

Although this Article draws on a wealth of congressional materials regarding the economic substance doctrine, the materials analyzed in this Article are a fraction of the materials regarding tax shelters more generally. Academic, practitioner, and journalistic commentary on the various legislative proposals for the economic substance doctrine undoubtedly also played an important role in shaping the codified version. And, of course, cases involving the economic substance doctrine as well as related doctrines were being litigated and decided over the course of Congress's long deliberation over the doctrine. Because of space constraints, this Article does not provide consideration of the broader historical context and its potential influence over congressional deliberation, though in some instances court decisions are discussed because they are raised directly in the congressional materials on the economic substance doctrine.

${ }^{13}$ The term "relevance provision" will be used throughout even though the precise term used in the statute is "relevant"-using "relevant provision" or similar as the descriptor would cause unnecessary confusion. See infra note 166 and accompanying text (discussing dictionary definitions of "relevant").

${ }^{14}$ See McMahon Jr., Living with Codified, supra note 2, at 737; Wells, supra note 12, at 417-18.

Tax Lawyer, Vol. 66 , No. 3 
cies' authoritative, reasonable interpretations of textual ambiguities. ${ }^{15}$ The economic substance legislative history acknowledges the general interpretive authority of the tax agencies but does not suggest a specific path for reconciling that authority with the preference that development of the doctrine continue "in the same manner" as under the common law. ${ }^{16}$ This Article proposes that the various strands in the legislative history can be reconciled by interpreting the relevance provision as adding two directions to tax agencies and courts: (1) the statute does not apply to transactions that are clearly consistent with the form and purpose of claimed tax benefits, and (2) the courts have final power to decide whether a specific, litigated transaction ultimately fails the requirements of the economic substance doctrine. ${ }^{17}$

Under this reading of the relevance provision, tax agencies would use their usual broad audit and litigation discretion in determining which transactions would be subjected to the rigors of the economic substance doctrine arena. ${ }^{18}$

${ }^{15}$ I.R.C. $\$ 7805$ (a). Multiple articles over many years address the tax agencies' interpretive authority and judicial deference. See, e.g., John F. Coverdale, Chevron's Reduced Domain: Judicial Review of Treasury Regulations and Revenue Rulings after Mead, 55 ADMIN. L. REv. 39, 72-92 (2003); Linda Galler, Judicial Deference to Revenue Rulings: Reconciling Divergent Standards, 56 Онго Sт. L.J. 1037 (1995); Kristin E. Hickman, The Need for Mead: Rejecting Tax Exceptionalism in Judicial Deference, 90 MINN. L. Rev. 1537 (2006); Leandra Lederman, The Fight Over 'Fighting Regs' and Judicial Deference in Tax Litigation, 92 B.U. L. REv. 643 (2012); Thomas W. Merrill \& Kathryn Tongue Watts, Agency Rules with the Force of Law: The Original Convention, 116 Harv. L. Rev. 467, 570-75 (2002); see also Mayo Found. for Med. Educ. \& Research v. United States, 131 S. Ct. 704, 713-14 (2011) (holding that regulations issued under section 7805(a) are analyzed under the Chevron line of cases).

For general discussion of Chevron U.S.A., Inc. v. Natural Res. Def. Council, 467 U.S. 837 (1984), and its progeny, see, for example, Stephen Breyer, Judicial Review of Questions of Law and Policy, 38 Admin. L. Rev. 363, 372-82 (1986); Evan J. Criddle, Chevron's Consensus, 88 B.U. L. Rev. 1271 (2008); Thomas W. Merrill \& Kristin E. Hickman, Chevron's Domain, 89 GeO. L.J. 833 (2001); Antonin Scalia, Judicial Deference to Administrative Interpretations of Law, 1989 Duke L.J. 511 (1989); Mark Seidenfeld, Chevron's Foundation, 86 Notre Dame L. Rev. 273 (2011); Cass R. Sunstein, Chevron Step Zero, 92 VA. L. Rev. 187 (2006).

${ }^{16}$ I.R.C. $\$ 7701(0)(5)(C)$. Theories regarding and discussion of the common law are also abundant. See, e.g., Ernest J. Brown, The Growing "Common Law" of Taxation, 34 S. CAL. L. Rev. 235 (1961); Frank B. Cross, Identifying the Virtues of the Common Law, 15 S. CT. Econ. Rev. 21 (2007); E. Donald Elliott, The Evolutionary Tradition in Jurisprudence, 85 Colum. L. Rev. 38 (1985); Jody S. Kraus, Transparency and Determinacy in Common Law Adjudication: A Philosophical Defense of Explanatory Economic Analysis, 93 VA. L. REv. 287 (2003); George L. Priest, The Common Law Process and the Selection of Efficient Rules, 6 J. Legal Stud. 65 (1977); Paul Rubin, Why Is the Common Law Efficient?, 6 J. Legal. Stud. 51 (1977); Jay Tidmarsh \& Brian J. Murray, A Theory of Federal Common Law, 100 Nw. U.L. Rev. 585 (2006); Todd J. Zywicki, The Rise and fall of Efficiency in The Common Law: A Supply-Side Analysis, 97 Nw. U.L. Rev. 1551 (2003).

${ }^{17}$ See infra Part III. The second proposed direction implicates the complicated (and confusing) line of cases on judicial deference. See infra Part IV.B (discussing Cheuron deference in context of proposed interpretation of relevance provision).

${ }^{18}$ For an overview of the tax agencies' audit and litigation functions, see BorIS I. BITTKER et al., Federal Income Taxation of Individuals gg 46.01-47.03, gg 51.01-.11 (3d ed. 2002); RiCHARDSON ET AL., supra note 7, at 93-286. 
Tax agencies also would have authority to issue court-binding regulations interpreting the requirements of the doctrine, but they would be constrained in their ability to issue court-binding regulations that directly provided in advance of litigation that a specific transaction failed the doctrine. This narrow constraint would ensure that courts would retain discretion as to the final thumbs-up, thumbs-down decision on the economic substance doctrine's ultimate relevance to a specific transaction. The scope of the economic substance doctrine standard would continue to emerge gradually and with flexibility through the issuance of agency guidance and, most critically, through the testing of multiple specific transactions on audit and in the courts. This reading emphasizes that Congress has declined to answer the question, "when is the economic substance doctrine relevant?" 19 in favor of providing guidance as to the question of, "who will determine whether the economic substance doctrine is relevant?"

Legislative history is, of course, only one tool of interpretation, and a highly controversial one at that. ${ }^{20}$ Even if one embraces more dynamic approaches to statutory interpretation, legislative history is still to be approached with caution; material relating to unenacted bills, such as the material used in this Article, falls under yet greater clouds of uncertainty. ${ }^{21}$ This Article thus briefly considers at various points the relevance provision in light of a textu-

\footnotetext{
${ }^{19}$ Monte A. Jackel, When Is the Economic Substance Doctrine Relevant?, 2011 TAx NotES Today 128-8 (July 4, 2011).

${ }^{20}$ See, e.g., Frank B. Cross, The Theory and Practice of Statutory Interpretation 24-84 (2009); William N. Eskridge, Jr, Dynamic Statutory Interpretation 207-38 (1994); William N. Eskridge, Jr et al., Legislation and Statutory Interpretation 303-22 (2006); Joseph L. Gerken, What Good Is Legislative History?: Justice Scalia in the Federal Courts of Appeals (2007); Kent Greenawalt, Legislation: Statutory Interpretation: 20 Questions 171-200 (1999); James J. Brudney \& Corey Ditslear, The Warp and Woof of Statutory Interpretation: Comparing Supreme Court Approaches in Tax Law and Workplace Law, 58 DUKE L.J. 1231 (2009); Frank H. Easterbrook, What Does Legislative History Tell Us?, 66 ChI.-Kent L. Rev. 441, 445 (1990); Jerry L. Mashaw, Textualism, Constitutionalism, and the Interpretation of Federal Statutes, 32 WM. \& MARY L. REv. 827 (1991); Adrian Vermeule, Legislative History and the Limits of Judicial Competence: The Untold Story of Holy Trinity Church, 50 StaN. L. Rev. 1833 (1998).

${ }^{21}$ See, e.g., EsKRIDGE, JR, supra note 20, at 222; EsKRIDGE, JR ET AL., supra note 20, at 307.
} 
alist approach to statutory interpretation that eschews legislative history. ${ }^{22}$ Textualists, who generally bear little love for the economic substance doctrine in the first place, ${ }^{23}$ may be inclined to read the codified doctrine as being relevant to a somewhat smaller group of transactions than would a judge willing to draw on the doctrine's broader enactment history. ${ }^{24}$

The activities of Treasury and the Service to date as to the codified economic substance doctrine suggest they are pursuing a strategy of asserting broad discretion as to how to deploy economic substance on audit and in litigation but resisting the issuance of any type of general guidance addressed to the public. ${ }^{25}$ The Article considers, however, the possibility of a change in the strategy of the tax agencies and posits three hypothetical regulations, including hypothetical regulations creating specific lists of transactions that pass or fail the economic substance doctrine. In the immediate aftermath of the codification of the economic substance doctrine, discussion of "angel" lists was common. ${ }^{26}$ This Article argues that particularized lists-whether "demon" or "angel" list regulations-should not be entitled to strong deference from the courts on the grounds that such lists either would exceed the authority implicitly delegated through the relevance provision's ambiguity or would not be reasonably consistent with the statutory text and structure. ${ }^{27}$

\footnotetext{
${ }^{22}$ For general discussion of statutory interpretation in the context of tax law, see Ellen Aprill, Theories of Statutory Interpretation: The Interpretive Voice, 38 Lox. L.A. L. REv. 2081 (2005); Noël B. Cunningham \& James R. Repetti, Textualism and Tax Shelters, 24 VA. TAx Rev. 1 (2004); Steven A. Dean \& Lawrence M. Solan, Tax Shelters and the Code: Navigating Between Text and Intent, $26 \mathrm{VA}$. TAx REv. 879 (2007); Brian Galle, Interpretative Theory and Tax Shelter Regulation, 26 VA. TAx REv. 357 (2006); Deborah A. Geier, Interpreting Tax Legislation: The Role of Purpose, 2 FLA. TAX REV. 492 (1995); Alan Gunn, Some Observations on the Interpretation Of the Internal Revenue Code, 63 TAxes 28 (1985); Mary L. Heen, Plain Meaning, the Tax Code, and Doctrinal Incoherence, 48 Hastings L.J. 771 (1997); Michael Livingston, Congress, the Courts, and the Code: Legislative History and the Interpretation of Tax Statutes, 69 TEx. L. Rev. 819 (1991); Allen D. Madison, The Tension Between Textualism and Substance-over-form Doctrines in Tax Law, 43 Santa Clara L. Rev. 699 (2003); Shannon Weeks McCormack, Tax Shelters and Statutory Interpretation: A Much Needed Purposive Approach, 2009 U. Ill. L. REv. 697 (2009); Lawrence Zelenak, Thinking About Nonliteral Interpretations of the Internal Revenue Code, 64 N.C.L. Rev. 623 (1986).

${ }^{23}$ See Coltec Indus. v. United States, 62 Fed. Cl. 716, 756 (2004), vacated by 454 F.3d 1340 (Fed. Cir. 2006) (suggesting common law economic substance doctrine violated separation of powers).

${ }^{24} \mathrm{~A}$ full discussion of textualism is beyond the scope of this Article. As a result, this Article utilizes something of a caricature when speculating as to the likely decisions of a textualist. See infra Part III.B.5. The authorities listed supra note 20, regarding legislative history, also generally discuss textualism. See also Caleb Nelson, What Is Textualism?, 91 VA. L. Rev. 347 (2005); John Manning, Textualism as a Nondelegation Doctrine, 97 Colum. L. Rev. 673 (1997); Jonathan R. Siegel, The Inexorable Radicalization of Textualism, 158 U. PA. L. Rev. 117 (2009).

${ }^{25}$ See infra Part IV.A.

${ }^{26}$ See McMahon Jr., Living with Codified, supra note 2; Wilkins Defends Economic Substance Doctrine, Schedule UTP, 2011 TAx Notes Today 209-3 (Oct. 31, 2011) (the Service's Chief Counsel reiterates that "Treasury or the IRS would not be putting out an angel list").

${ }^{27}$ See infra Part IV.B (discussing Cheuron line of cases).
} 
This argument depends, of course, on the persuasiveness of the assertion that the relevance provision indicates the congressional assignment of decisionmaking authority between courts and tax agencies.

The remainder of this Article is organized as follows: Part II provides a brief overview of the economic substance doctrine; Part III presents the proposed reading of the relevance provision; Part IV reviews the tax agencies' postcodification actions on economic substance and poses hypothetical regulations through which the tax agencies could move more aggressively to interpret the relevance provision's ambiguities; and Part V is a short conclusion.

\section{Economic Substance Doctrine Overview}

Courts have a long history in tax controversies of looking beyond the form employed by a taxpayer to the substance of a transaction. ${ }^{28}$ For example, under a general substance-over-form analysis, a court might decide that the technical owner of depreciable property does not own the property as a matter of substance; instead, some other person, the true tax owner, may claim the tax deductions. The economic substance doctrine is related to this substance-over-form tradition, but the doctrine looks more to a taxpayer's formal use of the tax law than to whether the underlying facts are as the taxpayer has claimed ${ }^{29}$ If a court uses the economic substance doctrine to reject a taxpayer's formal version of the tax law's operation, the taxpayer's entire transaction is treated as a substantive sham and all tax benefits are generally denied..$^{30}$ Thus, failure of the doctrine has a "no substance" effect; courts do not attempt to apply an alternate substantive law to the factual transaction undertaken by the taxpayer. ${ }^{31}$ Such a course is eminently pragmatic because the underlying facts of transactions without economic substance will make very little or no economic sense in the absence of the tax rules used by the taxpayers. ${ }^{32}$

This relationship between the facts of the abusive transaction and the taxpayers' use of tax law follows from the two inquiries of the economic substance doctrine test. The first inquiry is objective and asks whether "the transaction changes in a meaningful way (apart from federal income tax effects) the taxpayer's economic position." 33 In other words, the inquiry looks at whether the facts of the transaction still make objective economic sense even when

${ }^{28}$ See Luke, Risk, Return, supra note 2, at 787-90.

${ }^{29} \mathrm{Id}$. at 790.

${ }^{30}$ See Luke, Using an Ideal, supra note 2, at 116-17; Luke, Risk, Return, supra note 2, at 792. But see Economic Substance Doctrine May Apply to Securities Lending Scheme, 2012 TAx Notes Today 234-18 (Dec. 5, 2012) (Associate Chief Counsel memorandum stating, "When a transaction lacks economic substance, the Commissioner may disregard the parties' characterization of the transaction and treat the transaction according to its substance" (citing Rice's Toyota World, 752 F.2d 89, 95 (4th Cir.))).

${ }^{31}$ See Luke, Using an Ideal, supra note 2, at 117.

${ }^{32}$ In a prior article, I undertook an exploration of what a substiture law tied to the HaigSimons income definition might look like. Id. That article argued that the economic substance doctrine operates within the Haig-Simons norm.

${ }^{33}$ I.R.C. $\$ 7701(\mathrm{o})(1)(\mathrm{A})$. 
the claimed tax benefits are taken out of the equation. The second inquiry takes into account taxpayer motive, asking whether "the taxpayer has a substantial purpose (apart from federal income tax effects) for entering into such transaction." 34 Prior to codification, there was lack of uniformity in the courts regarding the phrasing and weight of these inquiries. ${ }^{35}$ Codification set the phrasing as quoted above and specified that failure of either statutory inquiry would cause the transaction to be disregarded. ${ }^{36}$

As the economic substance doctrine developed and gained court acceptance, the tax agencies' use of the doctrine also developed and evolved. By the time of codification, the economic substance doctrine had become an entrenched part of the tax agencies' audit and litigation arsenal. ${ }^{37}$ The tax agencies did not issue economic substance doctrine regulations, and reference to the economic substance doctrine is relatively sparse even in the most informal of pronouncements and rulings issued by the tax agencies. ${ }^{38}$ Tax agencies did, however, promulgate regulations that included broad anti-abuse language. ${ }^{39}$ Further, various disclosure requirements apply to transactions listed by the tax agencies as tax-avoidance transactions, and multiple such

${ }^{34}$ I.R.C. $\$ 7701$ (o)(1)(B). Codification provided some boundaries for how profit potential could be used and set expectations regarding the treatment of foreign taxes. See infra notes 124-32 and accompanying text. The Code section also clarified that the doctrine is not applicable to personal transactions. I.R.C. $\$ 7701$ (o)(5)(B).

${ }^{35}$ See Luke, Using an Ideal, supra note 2, at 115-18.

${ }^{36}$ See id. at 121.

${ }^{37}$ See discussion supra note 18.

${ }^{38} \mathrm{~A}$ handful of private letter rulings make mention of the doctrine in a substantive way. See P.L.R. 2008-07-015 (Nov. 7, 2007) (stating, in the alternative, that a "transaction generating the foreign tax credits lacked economic substance"); P.L.R. 1999-34-002 (May 24, 1999) (stating that the doctrine applies to a "compensation-related transaction"); P.L.R. 1999-10-046 (Nov. 16, 1998) (discussing application of doctrine to interest deduction); P.L.R. 1999-01-005 (Sept. 29, 1998) (discussing application of doctrine to interest deduction); P.L.R. 1998-12005 (Mar. 20, 1998) (treatment of corporate-owned life insurance contracts); see also C.C.A. 2009-15-033 (Dec. 24, 2008); C.A.M. 2008-40-040 (June 12, 2008); C.A.M. 2008-49-012 (June 4, 2008); C.A.M. 2008-26-036 (Feb. 29, 2008); F.S.A. 2002-02-057 (Oct. 11, 2001); F.S.A. 2001-43-004 (July 5, 2001); F.S.A. 2000-49-003 (Sept. 1, 2000).

${ }^{39}$ Reg. $\$ 1.701-2$ (general anti-abuse rules applicable to partnerships); Reg. $\$ 1.704-3$ (a) (10) (anti-abuse rule relating to disparities between value and basis at time of contribution to partnership). For discussion of partnership-related anti-abuse regulations, see Karen C. Burke, Castle Harbour: Economic Substance and the Overall-Tax-Effect Test, 107 TAx NoTEs (TA) 1163 (May 30, 2005); Karen C. Burke \& Grayson M.P. McCouch, Illusory Partnership Interests and the Anti-Abuse Rule, 132 TAx Notes (TA) 813 (Aug. 22, 2011); Alan Gunn, The Use and Misuse of Antiabuse Rules: Lessons from the Partnership Antiabuse Regulations, 54 SMU L. Rev. 159 (2001). 
transactions have been identified. ${ }^{40}$ Still, precodification, the tax agencies' primary means of influencing the economic substance doctrine was through their audit and litigation functions. ${ }^{41}$

Codification may have put an end to arguments that the economic substance doctrine was invalid because of a lack of statutory authority, but such quasi-tax-protester arguments comprised only a small part of the criticisms leveled at the doctrine. ${ }^{42}$ In particular, the stature does not directly address various "when" questions of economic substance: When will taxpayer action rise to the level of a "transaction?" When will such a transaction be scrutinized under the doctrine? When will the doctrine be applied in preference to other tax authorities? When will a transaction be likely to fail the inquiries of the doctrine? ${ }^{33}$ Critics of the doctrine might argue that the two inquiries of the economic substance doctrine are analogous to, and as useful as, the twin prongs of a divining rod. Such an assertion would be extreme, particularly given the history of actual transactions subjected to the doctrine. ${ }^{44}$ But it is fair to say that the common law economic substance doctrine carried with it an unofficial step that was more of a smell test than a formalized inquiry. ${ }^{45}$

The boundaries of this unofficial economic substance inquiry were necessarily amorphous because abusive tax avoidance schemes may be built from smaller bits of law and facts that are inert when kept apart but catch fire when combined. Indeed, the necessity of an economic substance standard lies in the practical impossibility of stating in advance all possible abusive permutations given the size and complexity of the tax system. Sometimes a smell test

${ }^{40}$ See I.R.C. $\$ 6111,6112,6662$ A, 6707, 6707A, 6708; Notice 2009-59, 2009-2 C.B. 170 (listed transactions update). The Service's website maintains a list of the current "listed" transactions. Listed Transactions - LBdI Tier I Issues, IRS, http://www.irs.gov/Businesses/Corporations/Listed-Transactions---LB\&I-Tier-I-Issues (last visited Feb. 17, 2013); see also Transactions of Interest-Not LMSB Tier I Issues, IRS, http://www.irs.gov/Businesses/Corporations/ Transactions-of-Interest---Not-LMSB-Tier-I-Issues (last visited Feb. 17, 2013) (transactions of interest).

For an overview of the "reportable transactions" regime and other tax shelter disclosure mechanisms, see Joshua D. Blank, Overcoming Overdisclosure: Toward Tax Shelter Detection, 56 UCLA L. Rev. 1629 (2009); Michael Doran, Tax Penalties and Tax Compliance, 46 Harv. J. oN Legrs. 111 (2009); Susan Cleary Morse, The How and Why of the New Public Corporation Tax Shelter Compliance Norm, 75 Ford. L. REv. 961 (2006).

${ }^{41}$ See supra note 18.

${ }^{42}$ See Luke, Using an Ideal, supra note 2, at 126.

${ }^{43}$ See Jackel, supra note 19 . The same questions were also raised regarding the common law. See, e.g., David Hariton, When and How Should the Economic Substance Doctrine Be Applied?, 60 TAX L. Rev. 29 (2006).

${ }^{44}$ See generally supra note 2 (referencing various articles regarding the economic substance doctrine).

${ }^{45}$ See Luke, Using an Ideal, supra note 2, at 171; see also Lederman, supra note 2, at 441 (the prongs of economic substance do "little to distinguish abuse cases from legitimate activity"). 
is the best available choice, even if there is a natural hesitation to state baldly that tax consequences hinge on a judgment call. ${ }^{46}$

The desire of taxpayers for immediate certainty and clear answers to questions about the doctrine's scope is even more understandable given the consequence of failing the doctrine. ${ }^{47}$ Codification left in place the "no substance" outcome for transactions failing the economic substance test. ${ }^{48}$ In addition to maintaining the doctrine's all-or-nothing approach to tax benefits, Congress raised the stakes by imposing a strict liability penalty of $20 \%$ ( $40 \%$ for undisclosed transactions) on any tax understatement resulting from failure to pass muster under the economic substance doctrine. ${ }^{49}$ These penalties also, however, alter the pragmatic and political considerations the tax agencies must weigh in determining how to enforce the doctrine. Rather than inspiring the agencies to use the doctrine aggressively, the strict liability penalty may, in the interest of avoiding political repercussions, cause the agencies to act with greater caution so that only obviously abusive transactions - and taxpayers-get hit with it. ${ }^{50}$ As will be discussed in Part IV, the tax agencies have been acting with greater caution than is statutorily required, but their current course also seems less likely to draw unwelcome scrutiny. ${ }^{51}$

\section{Reading Relevance}

This Part begins with background information regarding some underlying assumptions governing the proposed reading as well as an overview of the available sources of legislative history. The Part then turns to the interpretation of the relevance provision already mentioned in the Introduction: (1) the statute does not apply to transactions that are clearly consistent with the form and purpose of claimed tax benefits, and (2) the courts have final power to decide whether a specific, litigated transaction ultimately fails the requirements of the economic substance doctrine.

\footnotetext{
${ }^{46}$ See Mark P. Gergen, The Common Knowledge of Tax Abuse, 54 SMU L. Rev. 131, 142 (2001) ("Logic will take us only so far. Some decisions are not reducible to principles that can be stated authoritatively or that can be applied axiomatically.").

${ }^{47}$ See Neil Barr et al., Practitioners Want More Specifics on Codified Economic Substance Doctrine, 2011 TAX Notes Today 86-19 (May 4, 2011).

For a general discussion of the possible benefits and detriments of using tax law uncertainty, see Leigh Osofsky, The Case Against Strategic Tax Law Uncertainty, 64 Tax L. Rev. 489 (2011).

${ }^{48}$ I.R.C. $\$ 7701$ (o)(5)(a).

${ }^{49}$ The strict liability penalty follows from the combination of multiple Code provisions: I.R.C. $\$ \$ 6662$ (b)(6), 6664(c)(2), (d)(2); see also I.R.C. $\$ 6676$ (20\% penalty on excessive amount refund claim not eligible for "reasonable basis" defense if excess attributable to failing economic substance doctrine).

${ }^{50}$ See Charlene Luke, Three Once and Future Issues, 30 ABA Section of TAXation News Quarterly 1, 20 (2010).

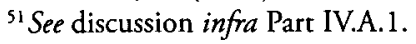




\section{A. Background Notes}

\section{Governing Assumptions}

This Article relies on a pragmatic, dynamic approach to statutory interpretation, with the goal of using legislative history to find an interpretation that will make sense of the textual language while ensuring a robust, flexible economic substance doctrine in the future. ${ }^{52}$ Clearly, multiple underlying assumptions are at work in the preceding statement, the defense of which is not possible given space constraints. ${ }^{53}$ The background section on economic substance will have to stand in for a fuller account of the importance of an anti-tax-avoidance standard. ${ }^{54}$ This Part contains suggestions throughout as to how a more textualist approach to the relevance provision might play out, ${ }^{55}$ but the Article does not engage in an analytical discussion of the various theories of statutory interpretation.

Even among those judges and scholars who accept the use of legislative history, there is extensive debate about how it should be used and which types are most acceptable. ${ }^{56}$ Again, this Article sidesteps an analysis of that underlying debate and organizes its use of legislative history within each point by adapting the ranking from most authoritative to least authoritative suggested by Professors Eskridge, Frickey, and Garrett. ${ }^{57}$ Under this ranking, committee reports relating to enacted language will be "the most authoritative evidence," followed by sponsor statements, colloquy or hearings, rejected proposals, and statements by others. ${ }^{58}$ Although the bulk of the legislative history on economic substance stems from unenacted bills, even early bills contain substantial portions of text that are identical to the final enacted version. The discussion of rejected language-language contained in earlier bills that does not appear in the final statute-uses a similar hierarchy of authoritativeness. ${ }^{59}$

\section{Sources of Economic Substance Legislative History}

This Part draws on committee reports and individual statements only if related directly to a "bill" containing economic substance language. The author's searches did turn up economic substance language in committee reports and in the congressional record that was not associated with a bill containing the doctrine. But a preliminary review of such material indicated it was repetitious of the language or discussion available through a consider-

\footnotetext{
${ }^{52}$ See, e.g., Cross, supra note 20, at 102-33; EsKRIDGE, JR, supra note 20, at 50-52.

${ }^{53}$ See supra note 20 (listing authorities on use of legislative history).

${ }^{54}$ See discussion supra Part II.

${ }^{55}$ See supra note 24; discussion infra Part III.B.5.

${ }^{56}$ See supra note 20 (listing authorities regarding legislative history).

${ }^{57}$ ESKRIDGE, JR. ET AL., supra note 20, at 222.

${ }^{58} \mathrm{Id}$. at 317.

${ }^{59}$ See, e.g., EsKridge, JR, supra note 20, at 222; EskRIdGe, JR ET AL., supra note 20, at 317.
} 
ation of only items formally labeled "bills" and their associated reports and statements. ${ }^{60}$

The first bill to address and to codify elements of the economic substance doctrine was expressly proposed in $1999 ;^{61}$ this was followed by numerous successive bills, roughly 70 in all, reflecting multiple versions of the doctrine and generating several committee reports and statements by sponsors and others. ${ }^{62}$ The relevance provision as eventually codified first appeared in a bill proposed in October $2007,{ }^{63}$ but the provision did not immediately appear in all subsequent bills. Instead, it competed with other versions that, although containing references to relevance, did not include the "in the same manner" and "never been enacted" language of the enacted relevance provision. ${ }^{64}$

The economic substance doctrine finally was codified as a minor provision of the Health Care and Education Reconciliation Act of 2010 (Healthcare Reconciliation Act). ${ }^{65}$ The Healthcare Reconciliation Act has only two documents associated with it; they are also the only two documents relating to bills containing the relevance provision. The most important of these is the "General Explanation" or "Blue Book" report issued by the Joint Committee

\footnotetext{
${ }^{60} \mathrm{All}$ searches were conducted using the LexisNexis service. The database groups searched for this project were: (1) Congressional Full Text of Bills for the 104th (coverage begins Jan. 1995) through 111 th Congresses (each Congress has a separate database); (2) "Committee Reports" (CMTRPT), which has partial coverage from 1990 and full coverage from 1994 forward of the full text of House and Senate Committee Reports; and (3) "Congressional Record" (RECORD), which contains the full text of the congressional record from Jan. 3, 1985 forward.

The economic substance doctrine was often considered in conjunction with other anti-taxavoidance measures-for example, enhanced disclosure requirements, anti-tax-haven provisions, and tax shelter promoter penalties. See, e.g., The Role of Professional Firms in the U.S. Tax Shelter Industry, S. Rep. No. 109-54 (2005) (prepared by S. Comm. on Homeland Sec. and Governmental Affairs). Consideration of congressional materials on those topics is beyond the scope of this Article.

${ }^{61}$ Abusive Tax Shelter Shutdown Act of 1999 , H.R. 2255, 106th Cong. $\$ 3$ (1999) (as introduced in the House, June 17, 1999).

62 "Roughly seventy," depending on how one counts bills; each numbered bill may include multiple versions. See Gail L. Richmond, Federal Tax Research 104 (8th ed. 2010). The Healthcare Reconciliation Act was the 71st bill to refer to the economic substance doctrine if one counts by unique bill numbers having at least one or more versions containing codification of economic substance doctrine elements. List of Economic Substance Bills (on file with author).

${ }^{63}$ Tax Reduction and Reform Act of 2007, H.R. 3970, 110th Cong. $\$ 3501$ (2007) (as introduced in the House, Oct. 25, 2007).

${ }^{64}$ See discussion infra Part III.C.2.

${ }^{65}$ Health Care and Education Reconciliation Act of 2010, Pub. L. No. 111-152, 124 Stat. 1047. This is the smaller of two acts that together comprised the total health care reform package. The other, larger act was the Patient Protection and Affordable Care Act, Pub L. No. 111-148, 124 Stat. 119 (2010).
} 
on Taxation. ${ }^{66}$ The "General Explanation" for the health care bills was issued in March 2011, one year after enactment. ${ }^{67}$ In March 2010, the Joint Committee also issued a "Technical Explanation" (JCT Technical Explanation) ${ }^{68}$ The passages on the economic substance doctrine in the two JCT documents are not identical; this Article relies on the 2011 "General Explanation" version (JCT Report), and the Article footnotes indicate places where the JCT Report departs from the JCT Technical Explanation. The JCT Report is the only document that relates to the finalized version of the economic substance text.

The second document given priority is a 2009 report issued by the House Committee on Ways and Means (2009 Ways and Means Report) ${ }^{69}$ that was reprinted in the House Committee on the Budget's report for the Healthcare Reconciliation Act. ${ }^{70}$ The 2009 Ways and Means report relates to a version of the economic substance doctrine that, while including the relevance provision, differed at a few points from the codified version. In general, the differences between the final JCT Report and the JCT Technical Explanation moved the JCT Report closer to the 2009 Ways and Means Report. The language of the economic substance doctrine as originally reported in the House in connection with the Healthcare Reconciliation Act matched that of the

\footnotetext{
${ }^{66}$ See Richmond, supra note 62, at 113-14 (discussing general importance of JCT reports); Brudney \& Ditslear, supra note 20, at 1280-83 (describing JCT and the importance of its expertise).

The Blue Book prepared by the Joint Committee on Taxation is not technically legislative history because it is not issued by Congress and it generally postdates the enacted legislation. See Estate of Hutchinson v. Commissioner, 765 F.2d 665, 670 (7th Cir. 1985); Michael Livingston, What's Blue and White and Not Quite as Good as a Committee Report: General Explanations and the Role of "Subsequent" Tax Legislative History, 11 AM. J. TAX PoL'Y 91 (1994). The Tax Court in Redlark v. Commissioner stated, "Where there is no corroboration in the actual legislative history, we shall not hesitate to disregard the General Explanation as afar as congressional intent is concerned." Redlark v. Commissioner, 106 T.C. 31, 45 (1996), rev'd, 141 F.3d 936 (9th Cir. 1998). In its review of Redlark, the Ninth Circuit expanded, "While such post-enactment explanations cannot properly be described as 'legislative history,' they are at least instructive as to the reasonableness of an agency's interpretation of a facially ambiguous statute." Redlark, 141 F.3d at 941.

The Tax Court later reversed its position as to the particular interpretive question at issue in Redlark and, in the process, also slightly modified its statement regarding materials prepared by the Joint Committee on Taxation: "[I]f a Blue Book were to conflict with enacted language or controlling legislative history, then the statutory language or the controlling legislative history would prevail." Robinson v. Commissioner, 119 T.C. 44, 65 (2002).

${ }^{67}$ Joint Comm. on Taxation, General Explanation of Tax Legislation Enacted IN THE 111TH CONGRESS, JCS-2-11 (2011), available at https://www.jct.gov/publications. html?func=showdown\&id=3777 [hereinafter JCT REP.]; see also JCX-20-1 1 (Mar. 23, 2011) (errata relating to the JCT REP.).

${ }^{68}$ Staff of the Joint Comm. on Taxation, Technical Explanation of the Revenue Provisions of the "Reconciliation ACt of 2010" as amended, in COMbination with the "Patient Protection and Affordable Care Act" (2011), available at https:/www.jct. gov/publications.html? func=fileinfo\&id $=3673$.
}

${ }^{69}$ H.R. REP. No. 111-299, pt. 2 (2009).

${ }^{70}$ H.R. Rep. No. 111-443, pt. 1, at 5 (2010). 
bill for which the 2009 Ways and Means Report was prepared. ${ }^{71}$ In keeping with the hierarchy of authoritativeness discussed above, when using legislative history, this Part gives priority to the JCT Report followed by the 2009 Ways and Means Report. If these items are silent or incomplete, then less authoritative sources are used to fill gaps and to provide additional support. These sources include seven other committee reports-four from the Senate Committee on Finance and three Conference Reports. ${ }^{72}$

\section{B. Clearly Consistent with Form and Purpose of Claimed Tax Benefits}

The text of the codified doctrine contains neither carve-outs for particular transactions nor general language regarding the interaction of the doctrine with other tax rules. ${ }^{73}$ The JCT Report and 2009 Ways and Means Report, as well as multiple other reports and statements, all support the position that even if a transaction technically fails one or more prongs of the economic substance doctrine, the transaction may still be saved by the taxpayer showing that the transaction is instead governed by a more specific provision or program..$^{74}$ Although this history may provide comfort to taxpayers genuinely concerned about routine business and investment transactions, the history is also almost entirely superfluous with respect to such activities because the same principle is readily derived from commonly used canons of construction $^{75}$ and from the application of the generally applicable burden of proof rules that apply in tax cases. ${ }^{76}$ The discussion in the legislative history regarding carve-outs should, however, give pause to promoters or other individuals planning elaborate transactions to generate tax benefits. The history suggests that courts should not take seriously taxpayer arguments that the fault is in the complexity or uncertainty of tax rules rather than in taxpayer obfuscations and arbitrage. The history also suggests that courts should use a purposive approach to judging whether a claimed tax provision governs instead of the economic substance doctrine. ${ }^{77}$

\footnotetext{
${ }^{71}$ Compare America's Affordable Health Choices Act of 2009, H.R. 3200, 111 th Cong. $\$ 452$ (2009), with H.R. REP. No. 111-299, pt. 2, at 55-56 (2009).

${ }^{72}$ S. Rep. No. 110-206, at 88 (2007); S. Rep. No. 109-336, at 137 (2006); H.R. Rep. No. 109-455, at 220 (2006) (Conf. Rep.); H.R. ReP. No. 108-755, at 650 (2004) (Conf. Rep.); S. Rep. No. 108-192, at 83 (2003); H.R. Rep. No. 108-126, at 44 (2003) (Conf. Rep.); S. Rep. No. 108-11, at 76 (2003).

${ }^{73}$ See Health Care and Education Reconciliation Act of 2010, Pub. L. No. 111-152, $\$ 1409$, 124 Stat. 1029, 1067-70.

${ }^{74}$ See JCT Rep., supra note 67, at 379-80; H.R. Rep. No. 111-299, pt. 2, at 291 (2009); Memorandum from Heather Maloy, Comm'r, Large Bus. \& Int'l Div., IRS, to Indus. Dirs., IRS (July 15, 2011), available at http:/www.irs.gov/Businesses/Guidance-for-Examiners-andManagers-on-the-Codified-Economic-Substance-Doctrine-and-Related-Penalties.

${ }^{75}$ See discussion infra Part III.B.5.

${ }^{76}$ See infra note 135.

${ }^{77}$ See discussion infra Part III.B.1.
} 


\section{1. "Clearly Consistent" with Purpose and Text}

The JCT Report provides as to the interaction of the economic substance doctrine with other tax rules, "If the realization of the tax benefits of a transaction is consistent with the Congressional purpose or plan that the tax benefits were designed by Congress to effectuate, it is not intended that such tax benefits be disallowed." ${ }^{\prime 8}$ This statement appears in a footnote immediately following the only discussion of the relevance provision contained in the JCT Report. ${ }^{79}$ The 2009 Ways and Means Report uses an even stronger phrasing, which also appears in a footnote relating to material discussing the relevance provision: "If the tax benefits are clearly consistent with all applicable provisions of the Code and the purposes of such provisions, it is not intended that such tax benefits be disallowed ... " ${ }^{80}$ Six earlier committee reports similarly stated, "If the tax benefits are clearly contemplated and expected by the language and purpose of the relevant authority, it is not intended that such tax benefits be disallowed." 81

All of these sources emphasize that any argument that a transaction is governed by a more specific tax benefit must take into account not only the plain language of the claimed tax benefit, but also the purposes behind that claimed benefit. The legislative history thus expressly contemplates a purposive approach to reading any other tax rules claimed by the taxpayer. All of the sources other than the JCT Report use the word "clearly" as the adverb, indicating the degree of certainty regarding the application of a claimed tax benefit over the economic substance doctrine. The JCT Report does not explain why it contains a different phrasing from all other prior reports, but both the JCT Report and 2009 Ways and Means Report make a point of quoting from a Federal Circuit decision: ${ }^{22}$

The Federal Circuit Court stated that "when the taxpayer claims a deduction, it is the taxpayer who bears the burden of proving that the transaction has economic substance." The Federal Circuit Court quoted a decision of its predecessor court, stating that "Gregory $v$. Helvering requires that a taxpayer carry an unusually heavy burden when he attempts to demonstrate that

${ }^{78} \mathrm{JCT}$ REP., supra note 67 , at 378 n. 1034.

${ }^{79}$ See infra note 156 and accompanying text.

${ }^{80}$ H.R. Rep. No. 111-299, pt. 2, at 291 n.124 (2009). The 2009 Ways and Means Report is identical to the enacted bill with respect to the relevance provision. See also S. REP. No. $110-$ 206, at 92 n. 126 (2007).

${ }^{81}$ S. Rep. No. 109-336, at 138 n.277 (2006); H.R. Rep. No. 109-455, at 223 n.365 (2006) (Conf. Rep.); H.R. Rep. No. 108-755, at 666 n.634 (2004) (Conf. Rep.); S. Rep. No. 108192, at 86 n.121 (2003); H.R. Rep. No. 108-126, at 46 n.52 (2003) (Conf. Rep.); S. Rep. No. 108-11, at 79 n.135 (2003). Reports using this language relate to a range of versions of the doctrine, but none of the unenacted versions included a more direct priority statement in the proposed legislative text.

${ }^{82}$ See Coltec Indus. v. United States, 454 F.3d 1340 (Fed. Cir. 2006). 
Congress intended to give favorable tax treatment to the kind of transaction that would never occur absent the motive of tax avoidance." 83

Use of this quotation is further indication that a clear showing of consistency with a deliberately provided tax benefit is required to save a transaction otherwise failing the objective or subjective inquiry of the economic substance doctrine.

The enumeration in the legislative history of two types of tax rules that may govern in place of the economic substance doctrine further suggests that clear application of such tax rules in place of the doctrine is required.

\section{Specific Incentives, Such As Credit Incentives}

The legislative history makes clear that properly utilized credits or similar incentives are not disallowed under the economic substance doctrine. The JCT Report specifically provides that "it is not intended that a tax credit... be disallowed in a transaction pursuant to which, in form and substance, a taxpayer makes the type of investment or undertakes the type of activity that the credit was intended to encourage." ${ }^{84}$ The JCT Report lists as examples the low-income housing credit, the production tax credit, the new markets tax credit, the rehabilitation credit, and the energy credit. ${ }^{85}$ The JCT Report does not, however, describe this list as a blanket carve-out ${ }^{86} \mathrm{~A}$ purposive analysis of the claimed credit provision is indicated through the language specifying that the transaction must conform "in form and substance" to the incentive. ${ }^{87}$

Multiple reports, including the JCT Report and 2009 Ways and Means Report, cite to Regulation section 1.269-2, which sets out circumstances

${ }^{83}$ JCT REP., supra note 67, at 371 n.998; H.R. Rep. No. 111-299, pt. 2, at 289 n.114 (2009). This same quotation appears in the other committee reports issued following the Federal Circuit's decision. S. Rep. No. 110-206, at 90 n.117 (2007); S. Rep. No. 109-336, at 137 n.270 (2006).

${ }^{84}$ JCT REP., supra note 67 , at 378-79 n.1034.

${ }^{85} \mathrm{Id}$. The Third Circuit recently used substance-over-form principles to determine that Pitney-Bowes could not receive the benefits of rehabilitation tax credits generated in a partnership because Pitney-Bowes was not substantively a partner. Historic Boardwalk Hall, LLC v. Commissioner, 694 F.3d 425 (3d Cir. 2012). The Tax Court had permitted the credits after application of the economic substance doctrine. Historic Boardwalk Hall, LLC v. Commissioner, 136 T.C. 1 (2011). The Third Circuit did not reach the economic substance doctrine issue. Historic Boardwalk Hall, 694 F.3d at 448 n.50. A redacted Field Attorney Advice memorandum similarly treated a party to an arrangement that effectively sold rehabilitation tax credits as being a nonpartner; the memorandum also, however, pointedly disagreed with the Tax Court's holding in Historic Boardwalk regarding the economic substance doctrine and concluded that the partnership lacked a nontax business purpose and was a sham. Historic Rehabilitation Partnership a Sham, IRS Concludes, 2013 Tax Notes Today 41-18 (Mar. 1, 2013).

${ }^{86} \mathrm{JCT}$ REP., supra note 67, at $378 \mathrm{n} .1035$.

${ }^{87}$ Id. at 378 n. 1034 . 
under which a "deduction, credit, or other allowance becomes unavailable." Under this Regulation, the effect of the deduction or credit must not distort the liability of the particular taxpayer when the essential nature of the transaction or situation is examined in the light of the basic purpose or plan designed by Congress. ${ }^{89}$ The citation in the committee reports suggests that similar considerations should determine whether a transaction is governed by a particular credit provision or instead may be subjected to the economic substance doctrine. Again, this indicates that the claimed credit must be clearly applicable to the transaction in terms not only of form but also of substance.

Statements made by individual legislators suggest that common tax rules, if their use is consistent with their form and purpose, would not lead to economic substance doctrine problems. For example, in a 2003 colloquy between Senator Rockefeller and Senator Baucus, Senator Baucus, as a cosponsor of the associated bill, assured Senator Rockefeller "that the new markets tax credit would not be adversely affected" by codification of the doctrine..$^{0}$ And in 2009, Senator Levin, as co-sponsor of a bill, explained, "Abusive tax shelters ... are very different from legitimate tax shelters, such as deducting the interest paid on a home mortgage or Congressionally approved tax deductions for building affordable housing." 91 This reference to the home

${ }^{88}$ Id; H.R. Rep. No. $111-299$, pt. 2, at 291 n.124 (2009); see also S. Rep. No. 110-206, at 92 n. 126 (2007); S. Rep. No. 109-336, at 139 n.278 (2006); H.R. Rep. No. 109-455, at 223 n.366 (2005) (Conf. Rep.); H.R. Rep No. 108-755, at 666 n.635 (2004) (Conf. Rep.); S. Rep. No. 108-192, at 86 n.122 (2003).

Section 269 applies only to certain acquisitions of corporate control and certain corporate liquidations. It is meant to prevent corporate tax attribute trafficking. James $\mathrm{C}$. Warner et al., C Corporations, BNA Tax Mgmt. Port. (BNA) 750-2nd, n.775 (2001).

${ }^{89}$ Reg. $\$ 1.269-2$.

${ }^{90} 150$ Cong. ReC. S5191 (daily ed. May 11, 2004) (cosponsor of Jumpstart Our Business Strength (JOBS) Act, S. 1637, 108th Cong. (2003)).

${ }^{91} 155$ Cong. Rec. S2625 (daily ed. Mar. 2, 2009) (statement of Sen. Levin) (relating to the Stop Tax Haven Abuse Act, S. 506, 11 th Cong. $\$ 401$ (2009)). Representative Poe, an opponent of the doctrine, did include in a congressional statement an anecdote involving a purchase by a sole proprietor and concluding that "[i]f the IRS decides he bought the new wrecker just to go fishing in it, they won't allow the tax write-off' using the economic substance doctrine. 155 Cong. Rec. H12430 (daily ed. Nov. 5, 2009) (relating to the Affordable Health Care for America Act, H.R. 3962, 111 th Cong. $\$ 562$ (2009)). The inability to claim depreciation for personal use assets is, however, well established; the economic substance doctrine is unnecessary and in any case is not applicable to personal transactions, a section which was in the proposed version to which Representative Poe referred. I.R.C. $\$ 7701$ (o)(5)(B) (2010). Conversely, the ability to claim depreciation for business use assets is "clearly consistent" with the Code, to use the phrases from the committee reports cited supra Part III.B.1. The burden is on the taxpayer to substantiate business use. See Temp. Reg. $\$ 1.274-5 T$.

Representative Poe's comment may have been influenced by a general distrust of the health care reform package. At the same time, as this Article argues, the statutory limits on the tax agencies' examination discretion are sufficiently low that an agent could test a sole proprietor's depreciation deductions under the economic substance doctrine, but in the absence of any additional complicating facts, the prudent course would be not to use the economic substance doctrine. 
mortgage interest deduction is striking because it suggests that the transactions most unlikely to be subject to the doctrine are those that squarely come within the scope of a clearly expressed, well entrenched tax benefit. When it comes to specific credits and deductions, the history provides only easy cases for purposes of identifying safe transactions. ${ }^{92}$

The two earliest bills dealing with economic substance actually contained a short angel list in the form of a list of credits, ${ }^{93}$ but such lists do not appear in later versions. The reason for the disappearance is not addressed directly in the legislative history but could relate to a concern that including enumerated statutory exceptions would merely provide determined tax avoiders with new building blocks for shelters. Indirect support for this argument comes from the history surrounding an unenacted provision on leases. Most unenacted bills proposed from 2001 through 2009 did contain a specific provision applicable to lessors of tangible property whereby profit potential would be tested without regard to common tax benefits such as depreciation

${ }^{92}$ See infra note 93.

${ }^{93}$ Small Business Tax Relief Act of 2000, H.R. 3874, 106th Cong. $\$ 266$ (2000); Abusive Tax Shelter Shutdown Act of 1999, H.R. 2255, 106th Cong. $\$ 3$ (1999). Both bills listed four credits: a "credit for producing fuel from a nonconventional source," "low-income housing credit," a credit for "electricity produced from certain renewable resources," and a "credit to holders of qualified zone academy bonds or any similar program hereafter enacted." In addition, the bills allowed inclusion of "[a]ny other tax benefit specified in regulations." 
and tax credits. ${ }^{94}$ Beginning in 2007 , some bill proposals omitted the provision regarding lessors, ${ }^{95}$ and, of course, the final codified version contains no such provision. ${ }^{96}$

The absence of a lease-specific provision from the final codified version and some earlier versions is not explained directly in the committee reports; the JCT Report and 2009 Ways and Means Report both state that "[l]easing transactions, like all other types of transactions, will continue to be analyzed in light of all the facts and circumstances." ${ }^{97}$ The change appears to be related to congressional concern regarding elaborate leasing schemes. ${ }^{98}$ In November 2007, Senator Conrad explained, in support of a bill omitting the lease

\begin{abstract}
${ }^{94}$ There were three distinct versions. One categorically stated that benefits of depreciation or of any tax credits would be ignored in calculating the expected net tax benefits. This was found in 15 bills, with dates ranging from 2001 to 2007. See, e.g., Abusive Tax Shelter Shutdown Act of 2001, H.R. 2520, 107th Cong. $\$ 2$ (2001); Abusive Tax Shelter Shutdown and Taxpayer Accountability Act of 2007, H.R. 2345, 110th Cong. $\$ 101$ (2007). The sole committee report relating to this version listed "the rehabilitation tax credit and the low income housing tax credit" as credits not taken into account. The report also specified that "a traditional leveraged lease is not affected by the bill to the extent it meets the present law standards. S. REP. No.
\end{abstract} 108-11, at 80 (2003); H.R. ReP. No. 108-126, at 48 (2003) (Conf. Rep.).

The second provided that regulations would determine whether a lessor satisfied the profit requirement. This version is found in four bills, all dating to 2003. See, e.g., Jobs \& Growth Reconciliation Tax Act of 2003, S.1054, 108th Cong. $\$ 301$ (as placed on Senate calendar, May 13, 2003). The committee report associated with this version provided instruction as to the content of the regulations: "A lessor of tangible property subject to a qualified lease shall be considered to have satisfied the profit test .... . [A] 'qualified lease' is a lease that satisfies the factors for advance ruling purposes as provided by the Treasury Department." H.R. REP. No. 108-126, at 48 (2003) (Conf. Rep.). The report then also specified that the tax benefit measurement should not include certain deductions or credits, including "the rehabilitation tax credit and the low income housing tax credit." Id. This report also concluded that "a traditional leveraged lease is not affected ... to the extent it meets the present law standards." Id.

The third version specified that depreciation, credits, or any other deduction "as provided in guidance by the Secretary" would be ignored in calculating the expected net tax benefits. This version was by far the most popular, appearing in 31 bills from mid-2003 through the beginning of 2009. See, e.g., Jumpstart Our Business Strength (JOBS) Act, S. 1637, 108th Cong. $\$ 401$ (2003); Julia Carson Responsible Fatherhood \& Healthy Families Act of 2009, H.R. 2979 , 111 th Cong. $\$ 204$ (2009). Committee reports relating to this third version provide the same examples of credits (e.g., "the rehabilitation tax credit and the low income housing tax credit") but do not include the statement regarding the safety of traditional leveraged leases. See S. Rep. No. 109-336, at 140 (2006); H.R. Rep. No. 109-455, at 225 (2006) (Conf. Rep.); H.R. Rep. No. 108-755, at 668 (2004) (Conf. Rep.); S Rep. No. 108-192, at 88 (2003).

${ }^{95}$ See, e.g., Heartland, Habitat, Harvest, and Horticulture Act of 2007, S. 2242, 110th Cong. $\$ 511$ (as placed on Senate calendar, Oct. 25, 2007).

${ }^{96}$ I.R.C. $\$ 7701(\mathrm{o})(5)(\mathrm{B})(2010)$.

${ }^{97}$ JCT Rep., supra note 67, at 379; H.R. Rep. No. 111-299, pt. 2, at 291 (2009); see also S. Rep. No. 110-206, at 93 (2007) (S. Comm. on Finance) (containing same language and relating to bill omitting lessor provision).

${ }^{98}$ These comments relate to SILO (sale-in, lease-out) and LILO (lease-in, lease-out) transactions. See Notice 2005-13, 2005-1 C.B. 630 (SILOs); Rev. Rul. 2002-69, 2002-2 C.B. 760 (LILOs). Both are listed transactions. See Notice 2009-59, 2009-2 C.B. 170 (2009); supra note 39; infra notes 286-90 (discussing "listed transactions").

Tax Lawyer, Vol. 66 , No. 3 
provision, that the bill "revokes tax benefits for leasing foreign subways and sewers." 99 He continued:

I know this is hard to believe, but there are actually companies and individuals who are reducing their U.S. taxes by buying foreign sewer systems, depreciating them on the books for U.S. tax purposes, and leasing those sewer systems back to the European cities that built them in the first place. ${ }^{100}$

If enacted, the special profit calculation rule for leasing transactions would not have protected such schemes, but the rule could have been used by promoters as cover. The removal of the leasing language thus hints at an intention to promote flexibility and to avoid handing new weapons to promoters. The absence of a statutory list of specific credits or other tax incentives may have been guided by similar concerns.

\section{Basic Business Transactions}

In addition to the mention of specific credits and deductions discussed above, the JCT Report does contain examples of slightly more complex business transactions that are unlikely to be abusive tax shelters. Thus, the JCT Report explained that the provision was "not intended to alter the tax treatment of certain basic business transactions." ${ }^{101}$ The JCT Report contains a noninclusive list of four examples:

(1) the choice between capitalizing a business enterprise with debt or equity; (2) a U.S. person's choice between utilizing a foreign corporation or a domestic corporation to make a foreign investment; (3) the choice to enter a transaction or series of transactions that constitute a corporate organization or reorganization under subchapter $C$; and (4) the choice to utilize a related-party entity in a transaction, provided that the arm's length standard of section 482 and other applicable concepts are satisfied. ${ }^{102}$

This same list of examples appears in the 2009 Ways and Means Report ${ }^{103}$ and also in a 2007 report by the Senate Committee on Finance. ${ }^{104}$ The appearance of this list in the committee reports coincides with the timing of the disappearance of the specific legislative language on leasing, and, as alluded to above, the reports further provide that leasing transactions were to be analyzed in light of all facts and circumstances. ${ }^{105}$

The "basic business transactions" list differs from the credits and deductions discussed in the prior section because business transactions generally

${ }^{99} 153$ ConG. ReC. S14602 (daily ed. Nov. 6, 2007) (relating to support of Senate amendment to Food and Energy Security Act of 2007, H.R. 2419, 110th Cong. (engrossed Senate amendment, Dec. 14, 2007)).

${ }^{100} 153$ Cong. Rec. S14602 (daily ed. Nov. 6, 2007).

${ }^{101}$ JCT REP., supra note 67, at 379.

${ }^{102}$ Id.

${ }^{103}$ H.R. Rep. No. 111-299, pt. 2, at 291 (2009).

${ }^{104}$ S. REP. No. 110-206, at 92 (2007).

${ }^{105}$ See supra notes 94-99 and accompanying text. 
involve an interaction of authorities rather than a single specific incentive provision. ${ }^{106}$ The reports containing this list all explain that such transactions are respected "under longstanding judicial and administrative practice," even though "the choice between meaningful economic alternatives is largely or entirely based on comparative tax advantages." 107 The cases cited include, for example, a Supreme Court case regarding the separate entity status of a corporation. ${ }^{108}$

The committee reports' discussion of basic business transactions makes clear, however, that such transactions are not absolute safe havens from the economic substance doctrine. The reports add two caveats (which would also apply to simpler credit or deduction incentives): (1) "whether a particular transaction meets the requirements for specific treatment under any of these provisions can be a question of facts and circumstances" and (2) "the fact that a transaction does meet the requirements for specific treatment . . is not determinative of whether a transaction or series of transactions of which it is a part has economic substance." ${ }^{109}$ A taxpayer may not escape the economic substance doctrine through labeling an activity as a "basic business transaction"; the facts and circumstances must clearly show that the transaction is in line with existing authorities.

Individual statements in the congressional record further indicate an effort to shield legitimate business planning, though the statements tend to carry more political than substantive content. In 2001, for example, Representative Doggett, as sponsor of a bill containing the doctrine, said that the doctrine would stop "deals that are done not to achieve economic gain in a competitive marketplace or for other legitimate business reasons but to generate losses that offer a way to avoid the tax collector." 110 Senator Baucus, as supporter of a bill sponsored by Senator Grassley, explained in 2003, "Care has been taken to avoid encumbering legitimate business transactions. . . . Without these changes, honest businesses will continue to be burdened to the extent they

\footnotetext{
${ }^{106}$ JCT REP., supra note 67, at 378-79.

${ }^{107}$ Id., at 379; H.R. REP. No. 111-299, pt. 2, at 291-92 (2009); S. REP. No. 110-206, at 92 (2007).

${ }^{108}$ JCT ReP., supra note 67, at 379; H.R. Rep. No. 111-299, pt. 2, at 291-92 (2009); S. Rep. No. 110-206, at 92 (2007) (citing Moline Properties, Inc. v. Commissioner, 319 U.S. 43 (1943)). Not cited is United Parcel Service of America, even though that case involved an unsuccessful attempt by the government to use the economic substance doctrine to deny benefits obtained through the strategic use of an offshore subsidiary. United Parcel Serv. of Am., Inc. v. Commissioner, 254 F.3d 1014 (11th Cir. 2001); see also infra notes 123 and 131.

${ }^{109}$ JCT REP., supra note 67, at 379 . In addition, the reports cite to case law that included analysis relating to the more general substance-over-form doctrine, thus recognizing that other judicial doctrines may prove more helpful than the economic substance doctrine in ensuring compliance.

${ }^{110} 147$ Cong. Rec. H4023 (daily ed. July 17, 2001) (statement of Rep. Doggett) (relating to Abusive Tax Shelter Shurdown Act of 2001, H.R. 2520, 107th Cong. (2001)).
} 
compete against companies avoiding taxes. Tax shelters . . are designed to achieve unwarranted tax benefits rather than business profit." 111

\section{Abusive Transactions}

The previous two sections discussed the types of transactions that are not to be targeted by the economic substance doctrine and concluded that the legislative history emphasizes a purposive reading of the claimed tax benefits, leaving room for the potential relevance of the doctrine even as to tax credits and basic business tax provisions. The legislative history also includes some guidance as to the types of transactions likely to be treated as shams under the doctrine, though this guidance is done primarily by referring to particular court cases.

The JCT Report and 2009 Ways and Means Report explained that " $[t]$ ax avoidance transactions have relied upon the interaction of highly technical tax law provisions to produce tax consequences not contemplated by Congress." 112 The JCT Report, 2009 Ways and Means Report, and several other committee reports also quoted approvingly from $A C M$ Partnership: ${ }^{113}$ "The doctrine of economic substance becomes applicable, and a judicial remedy is warranted, where a taxpayer seeks to claim tax benefits, unintended by Congress, by means of transactions that serve no economic purpose other than tax savings." ${ }^{114}$ These statements are consistent with a purposive approach requiring consideration of whether Congress did foresee the claimed tax benefit or whether the tax effects claimed by the taxpayer are unusual or surprising.

${ }^{111} 149$ Cong. Rec. S5008 (daily ed. Apr. 29, 2003) (statement of Sen. Baucus) (relating to CARE Act of 2003, S. 476, 108th Cong. (2003)). In another statement by Sen. Baucus as to the same bill, he further urged, "[I] $\mathbf{t}$ forces companies to engage in real business planning instead of tax-driven hoaxes." 149 Cong. Rec. S4930 (daily ed. Apr. 8, 2003) (statement of Sen. Baucus); see also 153 Cong. Rec. S14602 (daily ed. Nov. 16, 2007) (statement of Sen. Conrad saying that economic substance "is shutting down a bunch of tax scams that are going on around the country"); 155 Cong. Rec. S2625 (daily ed. Mar. 2, 2009) (statement of Sen. Levin) ("Abusive tax shelters are complicated transactions promoted to provide tax benefits unintended by the tax code.").

${ }^{112}$ JCT ReP., supra note 67, at 378; H.R. Rep. No. 111-299, pt. 2, at 290 (2008). This sentence is not contained in the JCT Technical Explanation. See also S. REP. No. 110-206, at 91 (2007) (same as JCT Report); S. Rep. No. 109-336, at 138 (2006) (S. Comm. on Finance) (same). A similar sentiment is found in the earliest committee report-a 2003 Senate Committee on Finance Report that explained, "The Committee is concerned that many taxpayers are engaging in tax avoidance transactions that rely on the interaction of highly technical tax law provisions. These transactions usually produce surprising results that were not contemplated by Congress." S. Rep. No. 108-11, at 89 (2003) (S. Comm. on Finance); S. Rep. No. 108-192, at 97 (2003) (S. Comm. on Finance) (same).

${ }^{113}$ ACM P'ship v. Commissioner, 157 F.3d 231 (3d Cir. 1998).

${ }^{114}$ JCT ReP., supra note 67, at 370; H.R. ReP. No. $111-299$, pt. 2, at 287 (2009); see also S. Rep. No. 110-206, at 89 (2007) (quoting ACM P'ship v. Commissioner); S. ReP. No. 109-336, at 135-36 (2006) (same); H.R. Rep. No. 109-455, at 220 (2006) (Conf. Rep.) (same); H.R. Rep. No. 108-755, at 664 (2004) (Conf. Rep.) (same); H.R. Rep. No. 108-126, at 44 (2003) (Conf. Rep.) (same). 
The text of the statute, the common law history, and the legislative history together show strong congressional agreement that appropriate cases were being litigated under the common law doctrine and disagreement with courts - and taxpayers - that took overly narrow views of the doctrine. ${ }^{115}$ The types of transactions targeted under the common law economic substance doctrine tended to be highly complex or to depend on unusual intersections of tax rules with each other and with various facts. ${ }^{116}$ The Service prevailed overwhelmingly in such cases, though not always on economic substance grounds. ${ }^{117}$ The success of the Service was noted approvingly in the JCT Report and in the 2009 Ways and Means Report: "Congress recognizes that the IRS has achieved a number of recent successes in litigation. The Congress believes it is still desirable to provide greater clarity . . . in order to improve its effectiveness at deterring unintended consequences." 118 These statements also suggest congressional trust in the stance of the Treasury and the Service on the economic substance audits and in litigation and in their prudential administration of the codified doctrine.

Codification functioned to overrule any judges inclined to avoid use of the doctrine on separation-of-power or textualist grounds. The JCT Report and 2009 Ways and Means Report singled out the Coltec decision, a Court of Federal Claims case in which a judge stated that "the use of the 'economic substance' doctrine to trump 'mere compliance with the Code' would violate the separation of powers." 119 While the Federal Claims decision was overturned on appeal, a desire to avoid such future judicial assertions is implicit in the JCT Report and in the 2009 Ways and Means Report. ${ }^{120}$ Both reports remarked with approval that the Federal Circuit had "overruled the Court of Federal Claims decision, reiterating the viability of the economic substance doctrine and concluding that the transaction in question violated the

\footnotetext{
${ }^{115}$ Nine enacted bills, including the earliest bill as well as bills into 2007 , contained a "findings" provision that stated, "Many corporate tax shelter transactions are complicated ways of accomplishing nothing aside from claimed tax benefits, and the legal opinions justifying those transactions take an inappropriately narrow and restrictive view of well-developed court doctrines ...." See, e.g., Abusive Tax Shelter Shutdown Act of 1999, H.R. 2255, 106th Cong. $\$ 2$ (as introduced in House, June 17, 1999); Abusive Tax Shelter Shutdown and Taxpayer Accountability Act of 2007, H.R. 2345, 110th Cong. $\$ 101$ (as introduced in House, May $16,2007)$.

${ }^{116}$ See Yoram Keinan, The Economic Substance Doctrine, 508-1st TAx Mgmt. Port. (BNA) $\$$ IX (2012) (listing economic substance doctrine cases by topic).

${ }^{117} \mathrm{Id}$.

${ }^{118}$ JCT Rep., supra note 67, at 378; H.R. REp. No. 111-299, pt. 2, at 290 (2008). These statements are not contained in the JCT Technical Explanation. JCT ReP., supra note 67, at 378; see also S. REP. No. 110-206, at 92 (2007) (same as JCT Report and 2009 Ways and Means Report).

${ }^{119}$ See JCT ReP., supra note 67, at 370-71; H.R. Rep. No. 111-299, pt. 2, at 288-89 (2009); Coltec Indus., Inc. v. United States, 62 Fed. Cl. 716, 756 (2004), vacated, 454 F.3d 1340 (Fed. Cir. 2006).

${ }^{120}$ See JCT ReP., supra note 67, at 370-71, 378; H.R. Rep. No. 111-299, pt. 2, at 288-90 (2009).
} 
doctrine." ${ }^{21}$ Coltec also appears by name in a statement made by Senator Grassley, a sponsor of an engrossed Senate amendment to an unenacted bill:

[I]t is for Congress to do the job of making the Tax Code on economic substance clear so the courts are not defining it, and most importantly so that four different courts aren't defining it in four different ways .... . It will also ensure that a court will not overturn the doctrine, as a trial judge did in what is called the Coltec case .... ${ }^{122}$

The text of the statute indicates disapproval of taxpayer victories in 2001 in two circuit court decisions, Compaq Computer Corp. and IES Industries, Inc., which involved the same basic transaction. ${ }^{123}$ The transaction relied for objective proof of economic substance on the presence of pretax profit, but if foreign taxes were taken into account, there was no pretax profit. ${ }^{124}$ The appellate courts agreed with the taxpayer's argument that pretax profit depended only on pre-U.S. tax profit. The codified doctrine evidences disapproval of those cases by providing that " $[t]$ he Secretary [of the Treasury] shall issue regulations requiring foreign taxes to be treated as expenses in determining pretax profit in appropriate cases." 25

This precise version of the foreign taxes provision does not appear in any prior bill, ${ }^{126}$ but consideration of prior unenacted versions makes clear that

${ }^{121}$ JCT ReP., supra note 67, at 371; H.R. REP. No. 111-299, pt. 2, at 289 (2009); see also H.R. Rep. No. 109-455, at 221 (2006) (Conf. Rep.) (raising the Coltec lower court decision in section on problems in the courts).

${ }^{122} 153$ Cong. Rec. $S 13952$ (daily ed. Nov. 6, 2007) (sponsor of engrossed Senate amendment to Food and Energy Security Act of 2007, H.R. 2419, 110th Cong. (2007)).

${ }^{123}$ Compaq Computer Corp. v. Commissioner, 277 F.3d 778 (5th Cir. 2001); IES Indus. v. United States, 253 F.3d 350 (8th Cir. 2001). The taxpayer victory most conspicuous for its absence in the history is United Parcel Service of America, Inc. v. Commissioner, 254 F.3d 1014 (11 th Cir. 2001), though the inapplicability of the doctrine to that case may have been signaled in the JCT Report and 2009 Ways and Means Report by virtue of the carve-out for "basic business transactions," discussed infra Part III.B.3. See also discussion of UPS case supra note 108 and infra note 131 .

${ }^{124}$ For discussion of the problems with the pretax profit test generally, see Luke, Risk, Return, supra note 2, at 793-803; Mitchell Kane, Compaq and IES: Putting the Tax Back into After-tax Income, 94 TAX Notes (TA) 1215 (Mar. 4, 2002); Michael S. Knoll, Compaq Redux: Implicit Taxes and the Question of Pre-tax Profit, 26 VA. TAX REv. 821 (2007); Terrance O'Reilly, Economics \& Economic Substance, 9 FLA. TAX REv. 755 (2010); Alvin C. Warren, Jr., The Requirement of Economic Profit in Tax Motivated Transactions, 59 TAXES 985 (1981).

${ }^{125}$ I.R.C. $\$ 7701$ (o)(2)(B). See discussion of regulations and the codified doctrine infra Parts III.C.3, IV.B.

${ }^{126}$ One bill contained virtually identical language except that "may" was substituted for "shall." American Workers, State, and Business Relief Act of 2010, H.R. 4213, 11 th Cong. $\$ 421$ (engrossed Senate amendment, Mar. 10, 2010).

Tax Lawyer, Vol. 66, No. 3 
this is indeed a reaction to Compaq and IES. ${ }^{127}$ Bills proposed before those court decisions did not contain a specific provision on foreign taxes, ${ }^{128}$ but following the taxpayer circuit court victories, nearly 60 bills were generated that proposed an even stronger version than the one eventually enacted of the foreign taxes provision. ${ }^{129}$ In 2003, Senator Grassley, again as a sponsor of economic substance legislation, remarked, "Last year, there were several court rulings that, in my view, misapplied this doctrine. These rulings now stand as legal precedent that can be used to justify abusive schemes in the future.

${ }^{127}$ See, e.g., H.R. 4213, 11 th Cong., 2d Sess. (2010); see also infra note 126 and text accompanying note 127. For further discussion of the Compaq and IES cases, see David P. Hariton, The Compaq Case, Notice 98-5, and Tax Shelters: The Theory Is All Wrong, 2002 Tax Notes Today 19-30 (Jan. 29, 2002); Kane, supra note 124; William A. Klein \& Kirk J. Stark, Compaq v. Commissioner-Where Is the Tax Arbitrage?, 94 TAx Notes (TA) 1335 (Mar. 11, 2002); Knoll, supra note 124; Luke, Risk, Return, supra note 2, at 816-25; Daniel N. Shaviro \& David A. Weisbach, The Fifth Circuit Gets It Wrong in Compaq v. Commissioner, 26 TAx Notes InT'L 191 (Apr. 15, 2002). The technique in these cases was foreclosed by enactment of Code section 901 (k). See Luke, Risk, Return, supra note 2, at 816 n.111.

${ }^{128}$ Abusive Tax Shelter Shurdown Act of 1999, H.R. 2255, 106th Cong. $\$ 3$ (as introduced in House, June 17, 1999); Small Business Tax Relief Act of 2000, H.R. 3874, 106th Cong. $\$ 266$ (as introduced in House, Mar. 9, 2000).

${ }^{129}$ The decision in IES Indus. v. United States was filed June 14, 2001. IES Indus. v. United States, 253 F.3d 350 (8th Cir. 2001). The first bill containing a provision on foreign taxes was introduced in July 2003. Abusive Tax Shelter Shutdown Act of 2001, H.R. 2520, 107th Cong. $\$ 101$ (as introduced in House, July 17, 2001). The stronger version, appearing in nearly 60 bills dating from 2001 through 2009, including the bill relating to the 2009 Ways and Means Report, provided that "foreign taxes shall be taken into account as expenses in determining pre-tax profit ..." See America's Affordable Health Choices Act of 2009, H.R. 3200, 111th Cong. $\$ 452$ (as introduced in House, July 14, 2009) (the complete list of bills containing this version is on file with author). A handful of bills even after 2001 had no foreign taxes provision at all. See, e.g., Food and Energy Security Act of 2007, H.R. 2419, 110th Cong. $\$ 12521$ (engrossed Senate amendment, Dec. 14, 2007). But, as will be discussed below, all bill versions, other than the one enacted, also had a specific provision regarding regulatory authority. See infra Part III.C.3. 
Today's clarification is intended to overturn those rulings." 130 It seems likely he was referring to the 2001 circuit court cases on foreign taxes, although since no case names are given, and the timing is not quite right, this cannot be said with certainty. ${ }^{131}$ In any event, Senator Grassley's comments reflect the view that the tax agencies were targeting transactions that merited economic substance doctrine scrutiny prior to codification.

\section{The Practical Effect of "Clearly Consistent" on Interpretation}

The legislative history material discussed above indicates that the economic substance doctrine will not be relevant if the taxpayer shows that the transaction is clearly consistent with both the form and purpose of the tax rules that are claimed to apply. This reading limits the ability of taxpayers to make arguments that transactions should be permitted unless expressly disallowed by the Code. To put it another way, Congress failing to say "no" to a particular transaction is not an acceptable defense to application of the economic substance doctrine. The legislative history suggests that taxpayers must instead show that Congress said "yes" to a particular tax benefit and to the structure used to obtain it.

For most taxpayers, this direction found in the legislative history will be inconsequential because commonplace transactions will be clearly consistent with congressional intent. Even in the unlikely event that the tax agencies were dramatically to shift to applying the economic substance doctrine to a widerange of commonplace, albeit tax-motivated, transactions, such an approach

${ }^{130} 149$ Cong. ReC. S4930 (daily ed. Apr. 8, 2003) (sponsor of CARE Act of 2003, S. 476, 108th Cong. (2003)). Although Senator Grassley, a Republican, was a sponsor of several bills containing the economic substance doctrine, he did not ultimately vote for its enactment. This is almost certainly because codification of the doctrine became enmeshed in the health care legislation. For example, the "job killer" epithet was used against the economic substance doctrine in the course of health care debate. See 155 Cong. REC. H12598 (daily ed. Nov. 7, 2009) (statement of Rep. Sessions); 155 Cong. Rec. H12258 (daily ed. Nov. 3, 2009) (statement of Rep. Foxx).

Early economic substance doctrine bills had some bipartisan support. Senators Coleman, Frist, Inhofe, Kyl, McCain, McConnell, Santorum, and Nickles all brought forward amendments that included codification of the doctrine, though most such proffers occurred in the context of a pressing need to address an unfavorable ruling by the World Trade Organization. See 150 Cong. Rec. S809 (daily ed. Feb. 20, 2004) (statement of Sen. Inhofe); 150 Cong. Rec. S5095 (statements of Sens. Kyl and McCain); 150 Cong. Rec. S3797 (daily ed. Apr. 6, 2004) (statements of Senators Kyl, Santorum, and Lieberman); 150 Cong. Rec. S3633 (daily ed. Apr. 5, 2004) (statement of Sen. Frist); 150 Cong. Rec. S3004 (daily ed. Mar. 23, 2004 ) (statements of Sens. Kyl and Nickles); 150 ConG. Rec. S2867 (daily ed. Mar. 22, 2004) (statement of Sen. McConnell on behalf of Sen. Frist); 150 Cong. Rec. S2111 (daily ed. Mar. 3, 2004) (statements of Sens. Grassley and Baucus, Santorum, and Lieberman); 151 Cong. Rec. S9472 (daily ed. July 29, 2005) (statement of Sens. Coleman, Levin, and Obama); see also David L. Brumbaugh, CRS Report Summarizes History of FSC/ETI Controversy, 2004 TAX Notes Today 232-16.

${ }^{131}$ See supra note 127 and accompanying text. Another 2001 taxpayer victory occurred in United Parcel Service of America, Inc. v. Commissioner, 254 F.3d 1014 (11 th Cit. 2001). See also supra notes 109 and 123. 
would not survive judicial scrutiny. The legislative history's emphasis on the taxpayer's burden could, however, be critical to an analysis of whether the economic substance doctrine treated uncommon, tax-motivated transactions as substantive shams. In the difficult cases, judicial approaches to statutory interpretation, including willingness to accept legislative history, could create judicial splits as to the ultimate relevance of the economic substance doctrine to particular transactions.

If confronted with a conflict between a claim by the taxpayer that a tax benefit is allowed by the Code and a claim by the Service of the relevance of the economic substance doctrine, a textualist judge ${ }^{132}$ may turn to a commonly used canon: "If there is a conflict between a general provision and a specific provision, the specific provision prevails." 133 If the specific provision applies, a textualist will use it over the more general doctrine. A textualist will, however, in turn interpret that more specific provision using the tools of textualism and thus also discount any legislative history that may shed light

${ }^{132}$ The textualist judge that is assumed for purposes of the discussion in this Article is something of a caricature but shares traits with other well-known textualists: text is primary; legislative history is anathema; text should be considered in context, including objective purposes discernible from the context; dictionaries may be used, with caution, if they reflect the background lexicon from which legislators were working; and canons of construction may be used, but also with caution and with greater trust in canons having do to with interpreting grammar and context. See Cross, supra note 20, at 51; see also supra note 24 (listing textualism authorities). See generally Antonin Scalia \& Bryan A. Garner, Reading Law: The InterPRETATION OF LEGAL TEXTs (2012) (discussing the textualist interpretive method). The book by Justice Scalia and Bryan Garner spurred a strong critique by Judge Richard Posner. Richard A. Posner, The Spirit Killeth, But the Letter Giveth Life, The New Republic, Sept. 13, 2012, at 18. Posner's critique was followed by a retort by Justice Scalia. See Terry Baynes, Fanning Furr, Justice Scalia Says Appeals Court Judge Lied, Reuters (Sept. 18, 2012), http://www. reuters.com/article/2012/09/18/us-usa-court-scalia-idUSBRE88H06X20120918. Justice Scalia's accusation led to a response by Judge Posner. See Richard Posner, Richard Posner Responds to Antonin Scalia's Accusation of Lying, ThE New Republic (Sep. 20, 2012), http://www.tnr.com/ blog/plank/107549/richard-posner-responds-antonin-scalias-accusation-lying\#.

${ }_{133}$ SCAlia \& GARNER, supra note 132, at 183; see also EsKridge, JR ET AL., supra note 20, at 275 . The use of statutory canons of construction is itself problematic. See, e.g., Karl N. Llewellyn, Remarks on The Theory of Appellate Decision and The Rules or Canons About How Statutes Are to Be Construed, 3 VAND. L. REv. 395, 401-06 (1950). 
on the purpose of that more specific provision. ${ }^{134}$ As alluded to above, for commonplace transactions, the end result should not vary depending on the judicial approach to interpretation. ${ }^{135}$

The cases where it is easy to determine that the economic substance doctrine does not apply are also those where it is highly likely that textualist tools of statutory construction would provide the same answer as an analysis making full use of the historical context. ${ }^{136}$ As discussed above, the legislative history is also clearest with respect to the easy cases, while it provides much less certainty as to which types of transactions are abusive. ${ }^{137}$ The "clearly consistent" direction provides guidance to courts and to tax agencies in their audit and examination functions, but it is open-ended guidance, leaving much to the discretion of the court with the final say on the transaction (consideration of the effect of tax agency rulemaking is deferred to Part IV). ${ }^{138}$ The effect of the "clearly consistent" direction on the tax agencies' audit and litigation functions will thus be almost entirely prudential. As will be argued more fully

\footnotetext{
${ }^{134}$ See Cross, supra note 20, at 85; Eskridge, JR. ET AL., supra note 20, at 228. Because the economic substance doctrine targets tax avoidance transactions, there may also be the possibility of judicial lenity, even though most economic substance cases do not contain even civil tax fraud allegations. Tax avoidance transactions are near cousins of fraudulent and criminal tax evasion. The strict liability penalty may further highlight that relationship in economic substance doctrine cases. See Kaye, supra note 12, at 600-04 (discussing controversy regarding strict liability penalty). There is thus some possibility that a court would subtly (or not so subtly) undermine the generally applicable standard of proof in civil cases. See also Kristin E. Hickman, Of Lenity, Chevron and KPMG, $26 \mathrm{VA}$. TAX Rev. 905, 911-32 (2007) (discussing tension between rule of lenity canon and deference doctrines in tax shelter cases); Steve R. Johnson, The Canon That Tax Penalties Should Be Strictly Construed, 3 NEv. L.J. 495, 522-24 (2003).

A more tax-specific canon is, however, in tension with any inclination to permit claimed tax benefits because of ambiguity in the governing tax law. That canon specifies that "exemptions from taxation are not to be implied; they must be unambiguously proved." See Brudney \& Ditslear, supra note 20, at 1296 (quoting Justice Brennan's majority opinion in United States v. Wells Fargo Bank, 485 U.S. 351 (1988)); see also Johnson, supra at 495 (listing various tax canons).

${ }^{135}$ The taxpayer generally has the burden of proof. Code section 7491 does shift the burden in a relatively narrow set of circumstances, and, of course, then only as to factual issues. See RichaRdson ET AL., supra note 7, at 223, 223 n.54; Steve R. Johnson, The Dangers of Symbolic Legislation: Perceptions and Realities of the New Burden-of-Proof Rules, 84 IowA L. Rev. 413, 414 (1999). The burden may also shift if formal tax fraud is alleged, if the government raises certain affirmative defenses, or as to matters not raised in the notice of tax deficiency. I.R.C $\$ 7454$; Johnson, supra note 135, at 485; see Richardson et al., supra note 7, at 223.

This Article does not address directly whether the economic substance determination is a question of law, fact, or mixed law and fact, although it assumes a legal component as to which tax agencies could issue interpretive regulations. The economic substance doctrine tests the boundaries between such categories because the doctrine involves a judgment call about whether a specific factual situation should legally be treated as real or not real. See Christopher M. Pietruszkiewicz, Economic Substance and the Standard of Review, 60 ALA. L. Rev. 339, 341 (2009).

${ }^{136}$ See Cross, supra note 20, at 52, 139; EsKRIDGE, JR, supra note 20, at 207-38.

${ }^{137}$ See discussion supra Parts III.B.2-3.

${ }^{138}$ See discussion supra Part III.B.4.
} 
in the next set of sections, the relevance provision did not impose unique restraints on these functions. ${ }^{139}$

Consider a hypothetical situation in which Congress has enacted a tax credit for the installation of solar panels. ${ }^{140} \mathrm{~A}$ taxpayer has complied with the terms for obtaining the credit, but he would never have installed solar panels in the absence of the credit. If the Service attempted to argue on audit that this taxpayer failed the subjective inquiry of the economic substance doctrine, courts would find for the taxpayer and would also likely hold that the government was not "substantially justified" in its position, thus possibly paving the way for the awarding of costs and fees to a taxpayer. ${ }^{141}$ The court might make a reference to the legislative history to support its rulings, but the same result is fairly certain even without use of the history, given the specificity of the credit provision when contrasted with the economic substance provision.

Imagine if the taxpayer had instead engaged in a much more elaborate transaction that derived tax benefits from the complex operation of multiple provisions, one small portion of which included use of the solar panel

\footnotetext{
${ }^{139}$ See discussion infra Part III.C.2.

${ }^{140}$ It should be noted that the solar panel hypotheticals that follow are not based on actual tax cases; indeed, because tax credits signal a congressionally approved deviation from the standard tax computation, it would require an exceptional set of facts for the economic substance doctrine to pose a problem. General substance-over-form doctrines (e.g., beneficial ownership, status of a partner) are far more likely to control in the event of suspected tax avoidance. See, e.g., Historic Boardwalk Hall, LLC v. Commissioner, 694 F.3d 425, 460-63 (3d Cir. 2012) (determining that taxpayer was not a partner and thus not eligible for a tax credit allocation); supra note 85. A Field Attorney Advice memorandum did, however, make a point of distinguishing Sacks v. Commissioner, 69 F.3d 982 (9th Cir. 1995), a case evaluating economic substance using an after-tax calculation because of the use of a solar panel tax credit. Historic Rehabilitation Partnership a Sham, IRS Concludes, 2013 Tax Notes Today 41-18 (Mar. 1, 2013). The memorandum did not address the codified doctrine, but it did draw a distinction between congressional intent "to encourage the underlying activity ... [and an intent regarding] the structure of this transaction." Id. Placing the burden on the taxpayer to show clear consistency with congressional intent is supported by the legislative history. And this Article uses a credit example to explore the outer boundaries of the comments in the legislative materials regarding credits and other basic business decisions. See supra Part III.B.3.

${ }^{141}$ Under Code section 7430, in order to recover such costs and fees, the taxpayer must satisfy various hurdles, including exhaustion of administrative remedies. See Ruchardson ET AL., supra note 7, at 126, 231-33 (discussing Code section 7430); Danshera Cords, Tax Protesters and Penalties: Ensuring Perceived Fairness and Mitigating Systemic Costs, 2005 B.Y.U. L. REv. $1515,1569-70$ (2005) (noting exhaustion of administrative remedies requirement); Doran, supra note 40 , at 122 (substantially justified "standard requires nothing more than that the government have a one-in-five chance of prevailing on the merits."). See generally Jeffrey $\mathrm{E}$. Quijano \& Rodney P. Mock, I.R.C. \$ 7430 Attorney's Fees: Navigating Section 7430 and A Call for The Final Act, 15 Ford. J. Cors. \& Fin. L. 731 (2010) (discussing various obstacles to a taxpayer's collection of attorney's fees).
} 
credit. ${ }^{142}$ The taxpayer then argues that the solar panel credit statute protects the entire gambit and that, at the very least, the panel credit should not be touched even if the rest of the edifice crumbles under the economic substance doctrine. On audit and in litigation, the Service argues for a broad view of "transaction" that takes away all the tax benefits, including the solar panel credit. In this situation, and in the absence of regulations on the definition of "transaction," the outcome is likely to be at least somewhat dependent on the particular view of the judge deciding the case. ${ }^{143}$ Variability of result is, however, consistent with the open-ended nature of the common-law-like approach embodied in the relevance provision.

A textualist, lower court judge may conclude that so long as the solar panels were actually installed, then the solar panel activity is a separate transaction and the credit stands. The judge should, however, also be more reluctant to award the taxpayer court costs. ${ }^{144}$ Some textualist judges may take a peek at congressional materials regarding the scope of the economic substance doctrine. But such a peek is unlikely to persuade the judge of having made the wrong decision; while the legislative history of the codified economic substance doctrine suggests that the taxpayer must demonstrate that Congress has said "yes" to the disputed transaction, the history does not expressly specify an interpretive method to use when evaluating congressional intent with respect to the claimed tax benefit. A textualist judge may decide that the taxpayer has persuasively shown that a particular narrow transaction-installation of the panels - was clearly consistent with the tax credit provision, as interpreted using textualist tools.

Consider, however, if the reviewing appellate panel is comprised of judges who adhere more to a pragmatic, dynamic model of staturory interpretation. Such judges will consider the legislative history for what it has to offer but are also more likely to agree that the economic substance doctrine is necessary to the integrity of the tax system. The appellate judges may determine that the "clearly consistent" requirement means the taxpayer has not prevailed and may cite language contained in committee reports-for example, language indicating congressional disapproval of unanticipated interactions of tax rules. ${ }^{145}$ As cases accumulate, the doctrine and the relevance provision would gradually acquire greater content, and the doctrine would be developing "in the same manner" as it developed before enactment.

\footnotetext{
${ }^{142}$ For example, the taxpayer could "partner" with a tax-exempt entity in a partnership that would funnel the credits to the taxpayer. See Historic Boardwalk Hall, LLC v. Commissioner, in which the court denied the benefit of rehabilitation credits under general substance-over-form doctrine, reversing the lower court, which had rejected the applicability of the economic substance doctrine. Historic Boardwalk Hall, LLC v. Commissioner, 694 F.3d 425 (3d Cir. 2012).

${ }^{143}$ See Cross, supra note 20, at 159-79 (discussing intersection of ideology, approach to statutory interpretation, and case outcomes).

${ }^{144}$ See Doran, supra note 40 , at 122.

${ }^{145}$ This Article does not take a position as to the appropriate standard of review on appeal. For a discussion of this issue, see Pietruszkiewicz, supra note 135, at 350-76.
} 


\section{Judicial Discretion As to Ultimate Relevance and Implications for Agency Guidance}

The interpretive conclusion reached in this section is less straightforwardly contained in the legislative history than the "clearly consistent" directive discussed above. This section will argue that the best reconciliation of the text, related statutes, and the legislative history is obtained through an interpretation under which courts retain final discretion as to whether a specific transaction ultimately fails the economic substance doctrine. This is, at its core, of course, simply an assertion that the codified economic substance doctrine functions essentially the same as any other statutory tax provision-with the courts being the final arbiters of the tax owed but with the agencies having substantial ability to constrain judicial discretion through regulations. The practical effects of this constraint, as well as a brief discussion of its path through the Chevron line of cases regarding judicial deference, are explored in Part IV.

\section{Uniform Phrasing of a Standard}

Codification of the economic substance doctrine has set a uniform phrasing for the two inquiries and for the requisite showing of pretax profit. ${ }^{146}$ The statute also makes clear that failure of either the subjective or objective inquiry will result in loss of tax benefits. ${ }^{147}$ In choosing among the various phrasings present in the circuit courts, the codified language generally uses the version that was considered more robust in terms of the ability of government to use the doctrine in targeting abusive transactions. For example, both the JCT Report and 2009 Ways and Means Report describe a "narrower approach used by some courts" through which a transaction would survive if either the objective or subjective inquiry were met. ${ }^{148}$ Similarly, the JCT Report and 2009 Ways and Means Report discuss how some cases allowed a "nominal amount" of pretax profit to carry a transaction. ${ }^{149}$ Earlier reports reflect this same concern. ${ }^{150}$

Although uniformity was of clear importance, uniformity achieved through codification was not meant to disrupt judicial flexibility. The concern was in having a uniform standard, not in providing uniform answers to whether

\footnotetext{
${ }^{146}$ See Luke, supra note 2, at 115-20.

${ }^{147}$ Health Care and Education Reconciliation Act of 2010, Pub. L. No. 111-152, $\$ 1409$, 124 Stat. 1029, 1068.

${ }^{148}$ JCT ReP., supra note 67, at 370; H.R. ReP. No. 111-299, pt. 2, at 288 (2009).

${ }^{149}$ JCT ReP., supra note 67, at 372; H.R. ReP. No. 111-299, pt. 2, at 289-90 (2009).

${ }^{150}$ See S. Rep. No. 110-206, at 90-91 (2007) (S. Comm. on Finance); S. Rep. No. 109-336, at 137 (2006) (S. Comm. on Finance); H.R. Rer. No. 109-455, at 222, 222 n.361 (2006) (Conf. Rep.); H.R. Rep. No. 108-755, at 665 (2004) (Conf. Rep.); S. Rep. No. 108-192, at 85 (2003) (S. Comm. on Finance); H.R. Rep. No. 108-126, at 46 (2003) (Conf. Rep.); S. Rep. No. 108-11, at 78 (2003) (S. Comm. on Finance).
} 
specific, future transactions would fail or survive the doctrine. ${ }^{151}$ The JCT Report and 2009 Ways and Means Report state, "A strictly rule-based tax system cannot efficiently prescribe the appropriate outcome of every conceivable transaction that might be devised and is, as a result, incapable of preventing all unintended consequences." 152 These reports then go on to explain that the common law economic substance doctrine was a standard, not a rule: "Many courts have long recognized the need to supplement tax rules with anti-taxavoidance standards, such as the economic substance doctrine, in order to assure the Congressional purpose is achieved." 153 Both reports also recognize that "[a]lthough these doctrines serve an important role in the administration of the tax system, they can be seen as at odds with an objective, 'rule-based' system of taxation." 154 The same or similar observations appear in several earlier committee reports as well. ${ }^{155}$

The JCT Report and 2009 Ways and Means Report quote from the relevance provision in the context of a discussion of court flexibility and uniformity. The JCT Report explains:

[The provision] does not alter the flexibility of the courts in other respects. The determination of whether the economic substance doctrine is relevant to a transaction is made in the same manner as if the provision had never been enacted. Thus, the provision does not change present law standards in determining when to utilize an economic substance analysis. ${ }^{156}$

${ }^{151}$ See S. Rep. No. 108-192, at 86 (2003) ("[T] he Committee is concerned that . . taxpayers are subject to different legal standards based on the circuit that the taxpayer is located. Thus, the Committee believes it is appropriate to clarify for the courts the appropriate standards to use in determining whether a transaction has economic substance."); S. REP. No. $108-11$, at 78 (2003) (same).

${ }^{152}$ JCT ReP., supra note 67, at 378; H.R. ReP. No. 111-299, pt. 2, at 290 (2009). The JCT Technical Explanation does not contain this statement.

${ }^{153}$ JCT ReP., supra note 67, at 378; H.R. REP. No. 111-299, pt. 2, at 290 (2009). The JCT Technical Explanation does not contain this statement.

The text of the codified doctrine, and all earlier bills save two, contains a definition of economic substance doctrine that emphasizes its common law roots: The term "economic substance doctrine" means the common law doctrine under which tax benefits with respect to a transaction are not allowable. I.R.C. $\$ 7701(\mathrm{o})(5)(\mathrm{A})$. Common law can, of course, develop rules as well as standards, but the common law of economic substance doctrine was far more a standard than a rule. See Luke, Risk, Return, supra note 2, at 797-98.

${ }^{154}$ JCT REP., supra note 67, at 369; H.R. REP. No. 111-299, pt. 2, at 287 (2009).

${ }^{155}$ S. Rep. No. 110-206, at 88, 92 (2007) (same as JCT Report and 2009 Ways and Means Report); S. Rer. No. 109-336, at 138 (2006) (same); see also H.R. Rep. No. 109-455, at 220 (2006) (Conf. Rep.) (containing only observation that "invocation of these doctrines can be seen as at odds with an objective, 'rule-based' system of taxation"); S. Rep. No. 108-192, at 83 (2003); H.R. Rer. No. 108-126, at 44 (2003) (Conf. Rep.) (same); S. Rer. No. 108-11, at 76 (2003) (same).

${ }^{156}$ JCT REP., supra note 67, at 378. The JCT Technical Explanation omits the sentence "the provision does not change such a transaction;" thus, it is the same as the 2009 Ways and Means Report as to this passage. 
The footnote in the JCT Report appearing at the end of the last sentence of this quotation contains the "consistent with the Congressional purpose" statement discussed above, ${ }^{157}$ thereby providing support for the linkage of the proposed constraint to the relevance provision text.

The statement in the 2009 Ways and Means Report is the same except that it omits the sentence "the provision does not change such transaction," and the footnote regarding consistency is also differently worded, as discussed above. ${ }^{158}$ The additional sentence in the JCT Report appears to relate to a footnote appearing in material not quoted above but immediately preceding it. That footnote explained that "transaction' includes a series of transactions," 159 suggesting that the sentence indicates that flexibility is also preserved as to whether activities should be grouped into a single transaction or not. ${ }^{160}$ Earlier committee reports relate to bills that did not contain the relevance provision, but they generally contain similar language-for example, "[ $t]$ he provision provides a uniform definition of economic substance, but does not alter the flexibility of the courts in other respects. ... Thus, the provision does not change current law standards used by courts in determining when to utilize an economic substance analysis." ${ }^{161}$ In the quotation above, language regarding consistency appeared at the ellipsis. ${ }^{162}$

\section{Preliminary Determination to Tax Agencies and Ultimate Determination to Courts}

The precise language of the relevance provision is central to this section: The determination of whether the economic substance doctrine is relevant to a transaction is made in the same manner as if this subsection had never been enacted. ${ }^{163}$ Dictionary definitions, for example, suggest that the word

\footnotetext{
${ }^{157}$ See supra notes $78-79$ and accompanying text.

${ }^{158}$ H.R. Rep. No. $111-299$, pt. 2, at 291 (2009).

${ }^{159}$ JCT REP., supra note 67, at $378 \mathrm{n} .1033$.
}

${ }^{160}$ The bill for which the 2009 Ways and Means Report was prepared did not contain a provision on series, whereas the final codified text did. A similar point regarding the ability of courts to aggregate and disaggregate is, however, contained in the JCT Report, 2009 Ways and Means Reports, and several others. See infra notes 184-86 and accompanying text.

${ }^{161}$ S. Rep. No. 110-206, at 92 (2007) (S. Comm. on Finance); see S. Rep. No. 109-336, at 138-39 (2006) (S. Comm. on Finance) ("The provision does not change current law standards used by courts in determining when to utilize an economic substance analysis .... The provision provides a uniform definition of economic substance, but does not alter the flexibility of the courts in other respects."); H.R. Rep. No. 109-455, at 223 (2006) (Conf. Rep.) (same); H.R. Rep. No. 108-755, at 666 (2004) (Conf. Rep.) (same); S. Rep. No. 108-192, at 86 (2003) (S. Comm. on Finance); H.R. Rep. No. 108-126, at 46 (2003) (Conf. Rep.); S. Rep. No. 108-11, at 79 (2003) (S. Comm. on Finance).

${ }^{162}$ S. Rep. No. 110-206, at 92 (2007); see S. Rep. No. 109-336, at 138-39 (2006) ("clearly contemplated" language appearing in footnote immediately preceding material on uniformity); H.R. Rer. No. 109-455, at 223 (2006) (Conf. Rep.) (same); H.R Rep No. 108-755, at 666 (2004) (same); S Rep. No. 108-192, at 86 (2004); H.R. Rer. No. 108-126, at 46 (2003) (Conf. Rep.); S. Rep. No. 108-11, at 79 (2003).

${ }^{163}$ I.R.C. $\$ 7701(0)(5)(C)$. 
"relevant" indicates a fairly low threshold-only that there be some "logical connection" between the doctrine and the transaction. ${ }^{164}$ This meaning is contained in the relevance provision, and the legislative history indicates that the agencies have primary oversight over preliminary decisions regarding the presence of a possible connection between a transaction and the economic substance doctrine. ${ }^{165}$ This assignment is, of course, also consistent with the general audit and litigation functions held by the tax agencies. ${ }^{166}$

In addition to "relevant" indicating a possible connection between the doctrine and a transaction, this section argues that the relevance provision also touches on whether a final connection will be made between the doctrine and a transaction-that is, whether the doctrine will ultimately be found relevant or not relevant. This is the question of most interest to taxpayers and tax practitioners. Audits and litigation unquestionably impose burdens on taxpayers, but the "when" question of most concern is when will a transaction ultimately fail or survive the application of the economic substance doctrine? The legislative history suggests that this meaning is also present in the relevance provision and that the decision as to the ultimate relevance of the economic substance doctrine to a transaction belongs to the courts. ${ }^{167}$

a. Evolution of Relevance. An understanding of the appearance of the relevance provision requires consideration of two competing versions of the introductory language for the statute. ${ }^{168}$ The first appears in a Novem-

${ }^{164}$ Black's Law Dictionary (9th ed. 2009) provides the following definition of "relevant": "Logically connected and tending to prove or disprove a matrer in issue; having appreciable probative value - that is, rationally tending to persuade people of the probability or possibility of some alleged facts." See also OxFORD ENGlish DictionARY (2d ed. 1989) ("relevant: 1.a. Bearing upon, connected with, pertinent to, the matter in hand."); WeBster's ThIRD NEw INT'L DicTIONARY (3d ed. 1993) ("relevant: 1: bearing upon or properly applying to the matter at hand: affording evidence tending to prove or disprove the matters at issue or under discussion: pertinent."); Merriam Webster's Online Dictionary, http://www.merriam-webster.com/dictionary/relevant (" $\mathrm{a}$ : having significant and demonstrable bearing on the matter at hand. b : affording evidence tending to prove or disprove the matter at issue or under discussion.").

For a discussion of the use of dictionaries in statutory interpretation (particularly textualism), see, for example, Ellen P. Aprill, The Law of the Word: Dictionary Shopping in the Supreme Court, 30 ARIz. ST. L.J. 275 (1998); Samuel A. Thumma \& Jeffrey L. Kirchmeier, The Lexicon Has Become a Fortress: The United States Supreme Court's Use of Dictionaries, 47 Buffalo L. REv. 227 (1999).

${ }^{165}$ Under certain conditions, courts may raise the doctrine sua sponte. Indeed, the doctrine had its origins in judicial decisions. See supra Part II.

${ }^{166}$ See Richardson ET AL., supra note 7.

167 See infra Part II.B.

${ }^{168}$ One other version of this introductory language is present in the unenacted bills. It is found in 21 bills from 2001 through mid-2007 and provides, "In applying the economic substance doctrine, the determination of whether a transaction has economic substance shall be made as provided in this paragraph." See, e.g., Abusive Tax Shelter Shutdown Act of 2001, H.R. 2520, 107th Cong. $\$ 101$ (as introduced in House, July 17, 2001); Abusive Tax Shelter Shutdown and Taxpayer Accountability Act of 2007, H.R. 2345, 110th Cong. $\$ 101$ (as introduced in House, May 16, 2007). This third version does not appear to have much bearing on the introduction of the relevance provision. 
ber 2003 bill and then is found in 39 bills through February 2010. ${ }^{169}$ The introductory language is as follows: "In any case in which a court determines that the economic substance doctrine is relevant for purposes of this title to a transaction (or series of transactions), such transaction (or series of transactions) shall have economic substance only if the requirements of this paragraph are met." ${ }^{\prime 70}$

The appearance of a second version of this introductory language occurred in tandem with the appearance of the "never been enacted" relevance provision; thus, the second version of the introductory language appeared in October 2007 and competed with the first, court-determination version up until the enactment bill. ${ }^{171}$ This second version appeared in nine bills, including the one enacted into law. ${ }^{172}$ The second version of the introductory language provides, "In the case of any transaction to which the economic substance doctrine is relevant, such transaction shall be treated as having economic substance only if [two inquiries are met]."173

In the fall of 2007, after multiple years of attempting to get economic substance codified over opposition, Senator Grassley, as cosponsor of an engrossed Senate amendment, introduced an innovation-not to the main economic substance doctrine provision but to the proposed penalty provision. He called the change "an improved version [that] has modifications made in response to concerns of taxpayers that codification would throw legitimate tax planning into question and allow the IRS to substitute its business judgment for that of the taxpayers." ${ }^{174}$ In his words:

We have heard complaints that a strict liability penalty will cause IRS field agents to overreach and courts to be reluctant to apply the doctrine. These are serious concerns, and we have addressed those concerns by requiring the IRS to nationally coordinate through the Chief Counsel's Office when the penalty is asserted and/or when it is compromised. This procedure is similar to a process currently used by the IRS to designate cases for litigation.

As a protective measure, taxpayers will be permitted to make their case to the IRS at the national level before a penalty is asserted. Of course, cases involving the economic substance doctrine should be going through Chief Counsel anyway, and taxpayers currently have the ability to persuade the IRS not to assert a penalty. But because of the strict liability nature of this

${ }^{169}$ H.R. 3650, 108th Cong. $\$ 101(2003)$.

${ }^{170}$ E.g., S. 2955, 111 th Cong. $\$ 2955$ (2010).

${ }^{171}$ See, e.g., Tax Reduction and Reform Act of 2007, H.R. 3970, 110th Cong. $\$ 3501$ (as introduced in House, Oct. 25, 2007); American Workers, State, and Business Relief Act of 2010, H.R. 4213, 111 th Cong. $\$ 421$ (engrossed Senate amendment, Mar. 10, 2010).

${ }^{172}$ E.g., I.R.C. $\$ 7701$ (o) (2010).

${ }^{173}$ See, e.g., I.R.C. $\$ 7701(0)$.

${ }^{174} 153$ Cong. Rec. S13952 (daily ed. Nov. 6, 2007) (relating to Food Energy Security Act of 2007, H.R. 2419, 110th Cong. $\$ 12521$ (engrossed Senate amendment, Dec. 14, 2007). The introduction of the Senate amendment is at 153 Cong. Rec. S13774 (daily ed. Nov. 5 , 2007). 
penalty, it is important to formalize this process and move it to a higher level of review.

Getting the Chief Counsel's Office involved earlier in this controversy will help taxpayers and the IRS resolve or make litigation decisions regarding tax shelters earlier. ${ }^{175}$

The proposed bill retained the court-relevance determination in the introductory language of the main Code provision but added relevance language to the penalty Code section:

The Chief Counsel ... may assert, compromise, or collect a penalty imposed by this section with respect to a noneconomic substance transaction even if there has not been a court determination that the economic substance doctrine was relevant ... to the transaction if the Chief Counsel (or delegate) determines that either was so relevant. ${ }^{176}$

This provision makes a distinction between preliminary relevance (to be determined by an administrative official) and ultimate relevance (to be determined by a court). The subsequent sentence in this penalty provision shows a conscious understanding that the use of court-determined relevance in the introductory language of the main statutory language is at odds with the need for the tax agencies to use the doctrine in the examination process. This sentence provides, "If there is a final order of a court that determines that the economic substance doctrine was not relevant for purposes of this title to a transaction (or series of transactions), any penalty imposed under this section with respect to the transaction (or series of transactions) shall be rescinded." 177

While there is no indication in the committee reports that the simultaneous move to a new version of the introductory language and the addition of the relevance provision were spurred by the problem exposed in the discussion relating to Senator Grassley's proposed version of the penalty provision, the timing is somewhat suggestive. ${ }^{178}$ That is, Senator Grassley's penalty relevance provision highlighted that a relevance determination by a court in the introductory provision was logically problematic given the need of the tax agencies to raise the doctrine in audits or in refund suits. The codified relevance provision sidesteps the problem by indicating that relevance is determined "in the same manner" as before. ${ }^{179}$ Under the common law at the time

${ }^{175} 153$ Cong. Rec. S13952 (daily ed. Nov. 6, 2007).

${ }^{176}$ See, e.g., Food and Energy Security Act of 2007, H.R. 2419, 110th Cong. $\$ 12522$ (engrossed Senate amendment, Dec. 14, 2007). This provision appears in eight bills. Although the introductory language in these bills contains the court determination of relevance provision, these eight bills did contain a change to the subjective inquiry, moving to the "substantial purpose" phrase used in the enacted language.

${ }_{177}$ See, e.g., H.R. 2419, 110th Cong. $\$ 12522$ (engrossed Senate amendment, Dec. 14, 2007).

${ }^{178}$ See supra note 60 and accompanying text for research methodology.

${ }^{179}$ See I.R.C. $\$ 7701(\mathrm{o})(5)(\mathrm{C})$. 
of enactment, preliminary relevance was being determined primarily by the tax agencies, with courts making ultimate relevance decisions. ${ }^{180}$

b. The Role of Courts. The legislative history emphasizes court flexibility, but it stops short of containing an unambiguous statement that courts have discretion over ultimate relevance. ${ }^{181}$ That courts have such discretion is instead inferred from an emphasis on court flexibility and from the multiple indications that the codified doctrine is to develop on a common-law-like path. ${ }^{182}$ In addition to the material on the common law standard already discussed above, ${ }^{183}$ the JCT Report and 2009 Ways and Means Report further indicate that codification "does not alter the court's ability to aggregate, disaggregate, or otherwise recharacterize a transaction when applying the doctrine." ${ }^{184}$ Both reports explain, "the provision reiterates the present-law ability of the courts to bifurcate a transaction in which independent activities with non-tax objectives are combined with an unrelated item having only tax-avoidance objectives in order to disallow those tax-motivated benefits." 185 Multiple earlier committee reports contain similar language, whether the related bill lacked a specific provision on series of transactions or instead wrapped series language into another provision, such as the introductory provision. ${ }^{186}$ The JCT Report, in connection with the foreign taxes provision discussed above, also contains a footnote providing that " $[\mathrm{t}]$ here is no intention to restrict the ability of the courts to consider the appropriate treatment of foreign taxes in particular cases, as under present law."187

c. The Role of Tax Agencies. The tax agencies figure more prominently in individual statements than in the committee reports. The main reference to a tax agency in a committee report was already quoted in the context of discussing uniformity goals: "The Congress recognizes that the IRS has achieved a number of recent successes in litigation. The Congress believes it is still desirable to provide greater clarity and uniformity in the application of the economic substance doctrine in order to improve its effectiveness at

\footnotetext{
${ }^{180}$ See supra Part III.C.2.

${ }^{181}$ See generally JCT ReP., supra note 67; H.R. Rer. No. 11 1-299, pt. 2 (2009) (explaining that the courts have flexibility, but not complete discretion, in determining relevance).

${ }^{182}$ See supra note 155.

${ }^{183}$ See supra Part III.C.1.

${ }^{184}$ JCT REP., supra note 67, at 379; H.R. REP. No. 111-299, pt. 2, at 292 (2009).

${ }^{185}$ JCT ReP., supra note 67, at 379-80; H.R. Rep. No. 111-299, pt. 2, at 292 (2009). These sentences also support the solar panel credit example discussed supra Part III.B.5.

${ }^{186}$ S. Rep. No. 110-206, at 93 (2007) (S. Comm. on Finance) (same as JCT Report); see also S. REP. No. 109-336, at 139 (2006) (S. Comm. on Finance) ("[T]he provision does not alter the court's ability to aggregate, disaggregate or otherwise recharacterize a transaction when applying the doctrine."); H.R. REP. No. 109-455, at 223 (2006) (Conf. Rep.) (same); H.R. Rep. No. 108-755, at 666 (2004) (Conf. Rep.) (same); S Rep. No. 108-192, at 86 (2003) (S. Comm. on Finance) (same); H.R. Rep. No. 108-126, at 46 (2003) (Conf. Rep.) (same); S. Rep. No. 108-11, at 79 (2003) (S. Comm. on Finance).

${ }^{187}$ JCT Rer., supra note 67, at $381 \mathrm{n} .1047$. This note does not appear in the JCT Technical Explanation.
} 
deterring unintended consequences." 188 Though ambiguous as to the referent, the "its" in the second sentence appears to refer to the "doctrine" rather than to the "IRS" in the preceding statement, but the overall indication is one in which the Service is to continue pursuing the same types of transactions as before.

Consideration of individual comments by legislators turns up a couple of statements suggestive of the need of the doctrine in tax agency audits or in litigation. Senator Graham of Florida commented in support of one bill: "While disclosure of these schemes by taxpayers and promoters can be useful in combating the proliferation of tax shelters, the IRS also needs some additional tools [referring to enactment of ESD]."189 Senator Levin, as a cosponsor of a bill containing the economic substance doctrine, observed, "Abusive tax shelters are usually tough to prosecute .... Abusive tax shelters . . . are often 'MEGOs,' meaning 'My Eyes Glaze Over.' Those who cook up these concoctions count on their complexity to escape scrutiny and public ire." 190 The overall context suggested that Senator Levin was discussing civil as well as criminal prosecution of tax shelters.

Concern over the potential aggressiveness of the tax agencies is easier to discern. Such concern is implied in two strands already discussed: the proposal for a relevance provision in the penalty statute and the statements of reassurance as to basic tax incentives and transactions. In addition, legislators opposed to the doctrine emphasized the power of the Service. Senator Hatch observed:

While I am certainly not in favor of abusive tax shelters, I am concerned that part of this package of antitax shelter provisions, known as the clarification of the economic substance doctrine, could also close down legitimate tax planning techniques and give the Internal Revenue Service an unprecedented degree of authority to recast the tax treatment of transactions it does not like, regardless of whether the transactions are otherwise allowed under the tax law. ${ }^{19 k}$

\footnotetext{
${ }^{188}$ JCT ReP., supra note 67, at 378; H.R. Rep. No. 111-299, pt. 2, at 290 (2009). These sentences do not appear in the JCT Technical Explanation.

${ }^{189} 149$ Cong. Rec. S4930 (daily ed. Apr. 8, 2003) (statement of Sen. Bob Graham) (relating to CARE Act of 2003, S. 476, 108th Cong. (2003)).

${ }_{190} 153$ Cong. Rec. S2204-05 (2007) (relating to Stop Tax Haven Abuse Act, S. 681, 110th Cong. (2007) (statement of Sen. Carl Levin). Senator Levin repeated these comments in 2009. Cong. Rec. S2624-01 (2009) (statement of Sen. Carl Levin) (relating to Stop Tax Haven Abuse Act, S. 506, 111 th Cong. (2009)).

${ }^{191} 149$ Cong. ReC. S5008-01 (2003) (statement of Sen. Orrin Hatch) (relating to CARE Act of 2003, S. 476, 108th Cong. (2003)). Senator Hatch made a similar statement in 2004, saying that he was pleased the economic substance doctrine was not enacted as it "would have led to a great deal of unnecessary conflicts between taxpayers and the Internal Revenue Service, and would have unfairly penalized companies for engaging in legitimate tax planning techniques." 150 Cong. Rec. S10967-01 (2004) (statement of Sen. Orrin Hatch) (relating to American Jobs Creation Act of 2004, H.R. 4520, 108th Cong. (2004)).
} 
Representative Poe, in the midst of the health care debates, argued that " $[t]$ he new health care bill also makes other legal tax deductions now illegal. This new tax is called the economic substance doctrine ... [T] he IRS would be able to decide what a person was thinking when they bought something."192 This latter remark is not consistent with the legislative history of the doctrine, nor does it reflect how the subjective inquiry works, but it is consistent with the view that the tax agencies would have primary oversight of the decision to test a transaction under the economic substance doctrine.

\section{Chevron-Deference Regulations Available for Doctrine Requirements, Not Specific Transactions}

The JCT Report provided, "As with other provisions in the Code, the Secretary has general authority to prescribe rules and regulations necessary for the enforcement of the provision," and cited in support of this sentence section 7805(a), which contains the general authority provision. ${ }^{193}$ The Supreme Court case confirming that regulations issued under this provision should be analyzed under the Cheuron framework was decided after codification of the doctrine but before the JCT Report was issued. ${ }^{194}$ All bills since April 2003, including the version of the Healthcare Reconciliation Act originally reported in the House, contained some version of a specific regulatory authority provision. ${ }^{195}$ The most common version, appearing in 59 bills, stated, "The Secretary shall prescribe such regulations as may be necessary or appropriate to carry out the purposes of this subsection. Such regulations may include exemptions from the application of this subsection." ${ }^{196}$ The originally reported Health-

${ }^{192} 155$ Cong. ReC. H12429-07 (2009) (statement of Rep. Ted Poe). Postcodification, the economic substance doctrine has been raised in arguments against adding more specific tax reforms. For example, Senator Kyl remarked, "Furthermore, Congress just gave the IRS another anti-abuse tool when it codified the economic substance doctrine as part of the healthcare bill." 156 Cong. Rec. S5412-01 (2010) (statement of Sen. Jon Kyl). Senator Enzi stated in opposition to reforms relating to the self-employment tax and $S$ corporations, "Plus, Congress has codified the economic substance doctrine which says a transaction must have an economic purpose aside from the reduction of tax liability in order to be considered valid. In my opinion, this is the IRS's ace-in-the-hole card. The IRS can close any loophole-real or imagined-with the power of the new law." 156 CONG. REC. S5240-03 (2010) (statement of Sen. Mike Enzi).

${ }^{193}$ JCT ReP., supra note 67, at 381 n.1048; see also Lederman, supra note 15, at 655-59 (discussing Code section 7805(a)); Merrill and Watts, supra note 15, at 570-75.

${ }^{194}$ Mayo Found. for Med. Educ. \& Research v. United States, 131 S. Ct. 704 (2011). Codification occurred in March 2010; the JCT Report (General Explanation) was issued in March 2011. The JCT Technical Explanation was issued in March 2010. See supra Part III.A.2. For a brief discussion of Cheuron, see infra Part IV.B.

${ }^{195}$ Reconciliation Act of 2010, H.R. 4872,111th Cong. $\$ 452$ (as reported in House, Mar. $17,2010)$. See supra note 60 for the research strategy employed to assemble bills addressing the economic substance doctrine.

${ }^{196}$ See, e.g., Taxpayer and Fairness Protection Act of 2003, H.R. 1661, 108th Cong. $\$ 111$ (as introduced in House, Apr. 8, 2003); Bipartisan Tax Fairness and Simplification Act of 2010, H.R. 3018, 111 th Cong. $\$ 411$ (as introduced in Senate, Feb. 23, 2010). 
care Reconciliation Act contained a version that had the first sentence but not the second. ${ }^{197}$ It is difficult to know what to make of the removal of the specific regulatory provision in the final versions of the Healthcare Reconciliation Act. ${ }^{198}$ The committee reports for prior bills did not comment on the regulatory authority but instead merely reproduced the regulations provision without comment. ${ }^{199}$

As discussed above, the codified version does direct the Secretary to promulgate regulations requiring that foreign taxes be included in the pretax profit calculation. ${ }^{200} \mathrm{~A}$ similar foreign taxes regulations statement is found in only one other bill before codification, and it provided: "The Secretary may issue regulations requiring foreign taxes to be treated as expenses in determining pretax profit in appropriate cases." ${ }^{201}$ Multiple unenacted bills also contained a specific mention of regulations in the context of developing a special profit calculation for lessors, ${ }^{202}$ but those bills contained both the specific provision and the more general statement about regulatory authority. ${ }^{203}$

It might be tempting to see the removal of the general provision and the addition of the specific foreign taxes provision as imposing a restriction on the issuance of general regulations claiming strong deference. ${ }^{204}$ If one takes the "never been enacted" language to a literal extreme, it also provides some support for this view as, prior to codification, regulations touching on economic substance would not have had a specific statute to interpret. ${ }^{205}$ At the same time, using the language contained in the relevance provision to make inapplicable a Code section as well entrenched as section 7805(a) would be

${ }^{197}$ Reconciliation Act of 2010, H.R. 4872, 111 th Cong. $\$ 452$ (as reported in House, Mar. 17, 2010).

${ }^{198}$ Health Care and Education Reconciliation Act of 2010, Pub. L. No. 111-152, $\$ 1409$, 124 Stat. 1029. Oddly, one postcodification bill contained a version of the economic substance doctrine containing the language on regulations. American Business Competitiveness Act of 2010, H.R. 5962, 111 th Cong. $\$ 501$ (as introduced in House, July 29, 2010) (this version also did not have the foreign taxes regulation provision).

${ }^{199}$ See, e.g., H.R. REP. No. 111-299, pt. 2, at 55, 293 (2009).

${ }^{200}$ See supra notes $123-31$ and accompanying text. For a discussion of the effects on taxpayers of statutory directions regarding regulations in the absence of promulgated regulations, see Amandeep S. Grewal, Substance Over Form? Phantom Regulations and the Internal Revenue Code, 7 Hous. Bus. \& TAx L.J. 42 (2006).

${ }^{201}$ American Workers, State, and Business Relief Act of 2010, H.R. 4213, 111th Cong. $\$ 421$ (engrossed Senate amendment, Mar. 10, 2010; introduced, Dec. 7, 2009; sponsors and cosponsors, Dec. 7, 2009).

${ }^{202}$ See supra notes 94-100 and accompanying text.

${ }^{203}$ See, e.g., Telephone Excise Tax Repeal Act of 2005, S. 1321, 109th Cong. $\$ 801$ (as reported in Senate, June 28, 2005).

${ }^{204}$ See, e.g., id.

${ }^{205}$ See supra note 39; infra notes 286-90 (discussing authorities issued under other Code sections regarding abusive transactions). 
odd, to say the least. ${ }^{206}$ In addition, courts generally assume structural coherence across the Code. ${ }^{207}$

\section{Consequences of Requirement That Codified Doctrine Evolve Like Common Law}

The legislative history supports that the "in the same manner" language of the relevance provision refers to a common-law-like, gradual evolution of the codified version. The specific references to "rules" and "standards" taps directly into scholarship regarding these concepts. ${ }^{208} \mathrm{~A}$ rule generally indicates a law that is more knowable ex ante; a standard gains content gradually through the accumulation of individual decisions. As a result, standards generate greater initial uncertainty but more fexibility. ${ }^{209}$

The fact of codification triggered the general authority granted in the Code to the tax agencies to issue interpretive regulations. ${ }^{210}$ This raises the question of the extent to which the tax agencies can specify the content of the economic substance doctrine in advance of a court ruling while still adhering to the statutory requirement of common-law-like expansions of the doctrine. The three basic interpretive choices would be, first, to argue that the relevance provision repealed that authority with respect to all but the foreign taxes provision of the economic substance doctrine. Second, the relevance provision could be read as providing no constraint at all on the issuance of interpretive regulations. The third course, which is the one proposed in this Article, is that the general interpretive authority largely applies to the doctrine, but that there is a line of specificity that tax agencies cannot cross and still expect strong deference. ${ }^{211}$ This approach reconciles the text and the history. It also offers a fairly narrow constraint and preserves the "smell" test quality of the common law doctrine. The boundaries of this reading of the relevance provision, as well as the placement of this argument within the discourse surrounding judicial deference, are explored in the next Part.

\section{The Service's Role}

As discussed in Part II, prior to codification, the substance of the doctrine was developing through a common law template-with the tax agencies' enforcement choices obviously having some influence on the direction the law was taking in the courts and with the tax agencies having a first mover

\footnotetext{
${ }^{206}$ See Brudney \& Ditslear, supra note 20, at 1269 ("The Justices invoke . . . the canon disfavoring implied repeals somewhat more often in tax cases.").

${ }^{207}$ See id. at 1298-300 (discussing "whole code" approach of Supreme Court in tax cases).

${ }^{208}$ See, e.g., Cass R. Sunstein, Problems with Rules, 83 Calif. L. Rev. 953, 956-57 (1995); Gergen, supra note 46, at 143; Louis Kaplow, Rules Versus Standards: An Economic Analysis, 42 DUKE L.J. 557, 559 (1992).

${ }^{209}$ For a discussion of the nature and effect of uncertainty in the Code, see generally, Osofsky, supra note 47.

${ }^{210}$ I.R.C. $\$ 7805(a)$

${ }^{211}$ See infra Part IV.B (briefly discussing Chevron deference).
} 
advantage because of their ability to raise the issue during audits. ${ }^{212}$ This Article argues that the relevance provision makes clear that the tax agencies' general discretion in framing issues during audit and on litigation was not directly expanded or contracted by the codified doctrine. ${ }^{213}$ In their exercise of rulemaking authority, tax agencies are limited only inasmuch as the final determination should remain within a court's discretion; thus, regulations that tread too closely to deciding directly the fate of an individual transaction are not entitled to strong deference under the proposed interpretation. ${ }^{214}$

This Part begins with an overview of the postcodification activity of the tax agencies; this activity is, so far, consistent with the interpretation of the relevance provision proposed in this Article. Subpart B uses three hypothetical regulations to explore briefly the argument that the relevance provision does pose some narrow constraints on the tax agencies' interpretive authority.

\section{A. Actions So Far}

The actions of the agencies to date are well within the bounds of the codified version. ${ }^{215}$ Indeed, they reflect a consciousness on the part of the agencies that codification cannot be taken lightly, particularly given the politics surrounding tax reduction, avoidance, and shelters. The guidance has virtually all been internal to the tax agencies, though available to the public. ${ }^{216}$ As a result, it can be said with high confidence that the material issued so far does not contain the notice or other formal requirements necessary to be in the

${ }^{212}$ See supra Part II.

${ }^{213}$ For an overview of the general audit and litigation functions of the tax agencies, see RICHARDSON ET AL., supra note 7.

${ }^{214}$ See supra Part I.

${ }^{215}$ See infra notes 218-19 and accompanying text. But see J. Leigh Griffith, 40 Percent Strict Liability Penalty: What Tax and Transaction Attorneys Need to Know, 48 TENN. BAR J. 18, 20 (2012) ("It appears the IRS will be aggressive.").

${ }^{216}$ Some further nuances of the tax agencies' approach might be gleaned from short verbal comments made at various conferences or other events by particular individuals, but an analysis of such offhand comments is not within the scope of this Article. See, e.g., Jeremiah Coder, Alexander Addresses Determination of Economic Substance Doctrine, 127 TAX Notes (TA) 1076 (June 7, 2010) (relating comments made by Service Associate Chief Counsel (Corporate) William Alexander "during a webcast sponsored by the New York State Bar Association Tax Section"). 
running for strong deference. ${ }^{217}$ Indeed, "guidance" is arguably too strong a word for the material issued to date, which, for the most part, does not purport to be interpretive in form; rather, it consists primarily of statements of internal policy regarding the audit and litigation functions of the tax agencies.

${ }^{217}$ This should be the result even given lingering confusion concerning the scope of Mead as applied to tax guidance after Mayo. Mayo v. United States held that Cheuron was the "appropriate framework" for analyzing tax regulations issued pursuant to Code section 7805(a) following notice and comment procedures. Mayo Found. for Educ. \& Research v. United States, 131 S. Ct. 704, 714 (2011). United States $\nu$. Mead created uncertainty regarding the procedures required to claim application of the Chevron framework. United States v. Mead Corp., 533 U.S. 218 (2001). Regulations issued through notice and comment procedures should generally be eligible for the framework. Id. at 227-28. As to other types of procedures, the Court commented, "we have sometimes found reasons for Cheuron deference even when no such administrative formality was required and none was afforded." Id. at 228. The Court in Mead observed that not only must Congress have delegated authority, but the agency interpretation must be "promulgated in the exercise of that authority." Id. at 227 . The internal agency pronouncements discussed in this Part contain disclaimers expressing that they are not legally binding. The public notice is framed as a request for comments and thus seems more likely to be a first step in obtaining Cheuron deference for future guidance. Mead itself held that tariff classifications were only entitled to Skidmore power of persuasion deference. See Hickman, supra note 15; Kristin E. Hickman \& Matthew D. Krueger, In Search of the Modern Skidmore Standard, 107 Colum. L. Rev. 1235 (2007); Lederman, supra note 15, at 665-68; Jim Rossi, Respecting Deference: Conceptualizing Skidmore within the Architecture of Chevron, 42 WM. \& Mary L. Rev. 1105 (2001). 


\section{Public Pronouncements}

Notice 2010-62 is to date the only significant economic substance doctrine guidance addressed to the public. ${ }^{218}$ It was issued by the IRS Office of Associate Chief Counsel (Procedure and Administration) on September 13, 2010 and was made retroactive to the date of the doctrine's enactment. ${ }^{219}$ The Notice is brief and seems to have been issued primarily to comfort taxpayers concerned that codification would trigger a more aggressive assertion

${ }^{218}$ Notice $2010-62,2010-2$ C.B. 411 . Other, less significant items addressed to the public
have come in two varieties. The first type implements or clarifies portions of Notice 2010-62.
For example, Notice $2010-62$ states that no private letter rulings will be issued as to the eco-
nomic substance doctrine. This was incorporated into the annual Revenue Procedure listing
areas that are "no ruling" areas beginning in 2012 . Rev. Proc. 2012-3, 2012-1 C.B. 113 ; see also
Rev. Proc. 2013-3, 2013 I.R.B. 113 (listing the doctrine again as a no ruling area for 2013).
In addition, a notice was issued streamlining the forms for the disclosure required by various anti-tax-avoidance Code sections. Announcement 2010-75, 2010-2 C.B. 428.

The second type consists of content-free hints that more future guidance will be forthcoming. Periodically, the Service and Treasury release a "priority guidance plan." This plan presents a list of projects at the tax agencies. These include or are accompanied by notices in which the tax agencies solicit "suggestions from all interested parties" in recognition of "the importance of public input to formulate a Priority Guidance Plan that focuses resources on guidance items that are most important to taxpayers and tax administration." Treasury, IRS Announce Release of 2010-11 Priority Guidance Plan, 2010 TAX Notes Today 235-38 (Dec. 8, 2010); see also IRS, Treasury Release 2011-2012 Priority Guidance Plan, 2011 Tax Notes Today 172-53 (Sept. 6, 2011) (using virtually identical language). Beginning with the priority guidance plan issued on December 7,2010, the economic substance doctrine has been appearing under the "Tax Administration" section. IRS, Treasury Release 2010-2011 Priority Guidance Plan, 2010 TAX Notes Today 235-25 (Dec. 8, 2010). The plans do not hint as to the form or content of the future guidance, and generally just list "[g]uidance under section 7701(o) and 6662(b)(6) regarding codification of the economic substance doctrine." IRS, Treasury Release 2012-2013 Priority Guidance Plan, 2012 Tax Notes Today 224-12 (Nov. 19, 2012); Updated 20112012 Priority Guidance Plan Adds 9 Projects, 2012 Tax Notes Today 83-57 (Apr. 30, 2012); Updated 2011-2012 Priority Guidance Plan Contains 14 New Items, 2012 TAx Notes TodaY 17-18 (Jan. 26, 2012); Updated 2011-2012 Priority Guidance Plan Includes 3 Recently Published Items, 2011 TAX Notes TODAY 212-40 (Nov. 2, 2011); IRS, Treasury Release 2011-2012 Priority Guidance Plan, 2011 TAx Notes Today 172-53 (Sept. 6, 2011); IRS, Treasury Release 2010-2011 Priority Guidance Plan, 2010 Tax Notes Today 235-25 (Dec. 8, 2010).

In the December 8,2010, plan, Notice 2010-62 is listed as being the guidance for that year. IRS, Treasury Release 2010-2011 Priority Guidance Plan, 2010 Tax Notes Today 23525 (Dec. 8, 2010). In subsequent years, the Notice is listed as prior guidance. See, e.g., IRS, Treasury Release 2012-2013 Priority Guidance Plan, 2012 Tax Notes Today 224-12 (Nov. 19, 2012).

${ }^{219}$ Notice 2010-62, 2010-2 C.B. 411 (providing "effective with respect to transactions entered into on or after March 31, 2010"). 
of the doctrine by the tax agencies. ${ }^{220}$ The Notice contains a one-paragraph section titled, "Determination of Economic Substance Transactions," which addresses the relevance provision. That paragraph, since it continues to represent the only direct statement on the relevance provision by a tax agency, is quoted in full:

Section $7701(0)(5)(C)$ provides that the determination of whether a transaction is subject to the economic substance doctrine shall be made in the same manner as if section 7701( 0 ) had never been enacted. In addition, section $7701(0)$ (1) only applies in the case of any transaction to which the economic substance doctrine is relevant. Consistent with these provisions, the IRS will continue to analyze when the economic substance doctrine will apply in the same fashion as it did prior to the enactment of section 7701(o). If authorities, prior to the enactment of section 7701(o), provided that the economic substance doctrine was not relevant to whether certain tax benefits are allowable, the IRS will continue to take the position that the economic substance doctrine is not relevant to whether those tax benefits are allowable. The IRS anticipates that the case law regarding the circumstances in which the economic substance doctrine is relevant will continue to develop. Consistent with section 7701(o) $(5)(C)$, codification of the economic substance doctrine should not affect the ongoing development of authorities on this issue. The Treasury Department and the IRS do not intend to issue general administrative guidance regarding the types of transactions to which the economic substance doctrine either applies or does not apply. ${ }^{221}$

This paragraph is a carefully worded exercise in making no statements that could end up harming the government in the future. The paragraph does not distinguish between preliminary testing under the economic substance doctrine and final determinations that a transaction fails the doctrine, but the overall impression is of an intention that transactions continue to be decided in the courts. ${ }^{222}$ The final two sentences suggest that the Service and Treasury

${ }^{220}$ Thus, the Notice summarizes the law and contains multiple express and implicit promises that the Service will not be attempting to undertake expansive renovations to the economic substance doctrine arena or to introduce a new array of transactions to that arena's tests. For example, "The IRS will continue to rely on relevant case law under the common-law economic substance doctrine .... In performing this calculation [profit], the IRS will apply existing relevant case law and other published guidance." Notice 2010-62, 2010-2 C.B. 411 . The Notice also contains rules regarding what will constitute "adequate disclosure" for purposes of the penalty provision.

${ }^{221}$ Notice 2010-62, 2010-2 C.B. 411 (emphasis in original).

${ }^{222}$ See id. "The IRS anticipates that the case law [on relevance] ... will continue to develop," and the Service does not intend to issue general guidance "regarding the types of transactions as to which the economic substance doctrine either applies or does not apply.").

In addition to the paragraph about relevance, the Notice also provides, "The IRS will not issue a private letter ruling or determination letter . . . regarding whether the economic substance doctrine is relevant to any transaction or whether any transaction complies with the requirements of section 7701 (o)." Id. The "or" is interesting in that it may suggest a distinction between testing a transaction and the more final decision that a transaction is or is not in compliance. 
are reading the relevance provision as limiting their ability to issue overly specific guidance regarding individual transactions, though the sentences also leave plenty of room for the tax agencies to argue that they have not conceded that point. While Notice 2010-62 is not all that illuminating regarding the tax agencies' interpretation of the relevance provision, the Notice is clearly not inconsistent with the interpretation of the relevance provision advanced in this Article and provides some indirect support for it as well.

\section{Internal Policies}

Internal policy guidance provides a clearer sense of the tax agencies' approach to the codified doctrine. The terms of these internal policies are not inconsistent with the relevance provision interpreted here, but they also reflect a quite cautious approach to the implementation of the doctrine. ${ }^{223}$ On July 15, 2011, the Commissioner of the Service's Large Business and International Division issued a directive (LB\&I directive) aimed at various

${ }^{223}$ Two recently released internal memoranda have been judged by practitioners as being aggressive. See Amy S. Elliott, IRS Memo on Securities Lending Is Wrong, Practioners Say, 2013 Tax Notes Today 25-3 (Feb. 6, 2013); Shamik Trivedi, No Surprises, Just Disappointment with IRS Memo on Rehabilitation Credits, 2013 Tax Notes Today $41-2$ (Mar. 1, 2013). Neither memorandum addresses the codified doctrine, but as both were issued postcodification, the approach taken in them will be (and already has been) closely scrutinized for signs about the possible future intentions of the tax agencies. Neither memorandum addresses the 2011 LB\&I directive discussed in the main text, presumably because the directive applied to implementing the codified doctrine and the memoranda address transactions entered into prior to codification.

The first was written by Associate Chief Counsel (International) to a Program Manager for Large Business and International. It concluded that the economic substance doctrine could be applied to securities lending transactions designed to completely eliminate withholding taxes. Economic Substance Doctrine May Apply to Securities Lending Scheme, 2012 Tax Notes Today 234-18 (Dec. 5, 2012). The memorandum emphasizes the transaction's lack of a nontax business purpose in reaching its conclusion.

The second was addressed to a field attorney in Large Business and International by an Associate Area Counsel. Historic Rehabilitation Partnership a Sham, IRS Concludes, 2013 TAX Notes Today 41-18 (March 1, 2013). It provides some sense of the possible direction agents may take in discerning congressional intent. Like the securities lending memorandum, the rehabilitation credit memorandum emphasized the presence of nontax business purpose. The credit memorandum also indicated that claimed benefits must be supported by congressional intent as to the structure used to obtain the benefits. The memorandum states, "it cannot be said that the structure of this transaction - that is, the alleged partnership arrangement between the [formal partner] and [the partnership]-is so 'unmistakably within the contemplation of congressional intent,' . . . as to warrant departure from the normal application of the shampartnership doctrine." Id. Although the memorandum speaks in terms of a "sham-partnership doctrine," it references economic substance cases. The rehabilitation memorandum's approach is consistent with the legislative history regarding the application of the codified economic substance doctrine when tax credits or similar benefits are at stake. 
directors over various categories of Service agents. ${ }^{224}$ Its stated purpose was "to instruct examiners and their managers how to determine when it is appropriate to seek the approval of the DFO [director of field operations] in order to raise the economic substance doctrine."225 Thus, the LB\&I directive is aimed at providing guidance as to when applying the economic substance doctrine would or would not likely be "appropriate" during audits. ${ }^{226}$ The directive states, "Once an examiner determines that raising the doctrine may be appropriate, this directive sets forth a series of inquiries the examiner must develop and analyze in order to seek approval for the ultimate application of the doctrine in the examination."227

The examination framework developed in the directive shows considerable restraint and concern for taxpayers. For example, it provides that the examiner "shall notify a taxpayer that the examiner is considering whether to apply the economic substance doctrine to a particular transaction as soon as possible, but not later than when the examiner begins the analysis ..."228 This

${ }^{224}$ IRS Issues LB\&I Directive on Codifed Economic Substance Doctrine and Penalties, 2011 TAX Notes Today 137-17 (July 18, 2011). For a general discussion of the directive, see Robert S. Chase II et al., Economic Substance Directive: Some Substance, Many Questions, 132 TAX Notes (TA) 828 (Aug. 22, 2011); David C. Garlock et al., Analysis of the LBEI Directive on the Economic Substance Doctrine, 133 TAx Notes (TA) 193 (Oct. 10, 2011); Richard M. Lipton, IRS Provides Helpful Guidance to Agents as to Application of the Economic Substance Doctrine, 115 J. TAX. 116 (2011); Lee A. Sheppard, IRS Repeal of the Economic Substance Statute, 2012 TAX Notes Today 34-1 (Feb. 21, 2012).

This major LB\&I directive was preceded by a much shorter directive issued in September of 2010 by the Commissioner of the Service's Large and Mid-Size Business Division, the predecessor to LB\&I (the LMSB directive). The LMSB directive was aimed at allaying concerns among taxpayers and practitioners about the strict liability penalty, although the directive expressly stated a warning: "This Directive is not an official pronouncement of law, and cannot be used, cited, or relied upon as such." Economic Substance Doctrine Penalty Must Be Approved by Field Director, LMSB Directive Says, 2010 Tax Notes Today 178-47 (Sept. 15, 2010). The directive's central guidance consists of a single sentence: "To ensure consistent administration of the accuracy-related penalty imposed under section 6662(b)(6), any proposal to impose a section $6662(\mathrm{~b})(6)$ penalty at the examination level must be reviewed and approved by the appropriate Director of Field Operations before the penalty is proposed." Id.

The codified economic substance doctrine has also been added to at least one audit technique guide; such guides are issued to examiners and address a particular industry or topic. In July 2011, the Service issued a revised guide for the "business consulting industry." IRS Releases Business Consultants Audit Techniques Guide, 2011 Tax Notes Today 133-39 (July 12, 2011). The guide listed the doctrine but did not provide substantive guidance as to its content. In addition to the economic substance doctrine, the guide also added related items: "the shifting or assignment of income issue and the substance versus form issue." Id.

${ }^{225}$ IRS Issues LB\&I Directive on Codiffed Economic Substance Doctrine and Penalties, 2011 Tax Notes Today 137-17 (July 18, 2011).

${ }^{226}$ The directive uses the word "relevant" only when quoting from the statute. Id. The directive was specifically addressed to "industry directors director, field specialists director, pre-filing and technical guidance director, international business compliance director, international individual compliance." Id.

${ }^{227}$ Id.

${ }^{228}$ Id.

Tax Lawyer, Vol. 66 , No. 3 
notice requirement is not, however, intended to provide additional taxpayer rights. Indeed, the directive states that it "is not an official pronouncement of law, and cannot be used, cired, or relied upon as such." 229 The directive is, however, also careful to make no absolute statements regarding when the economic substance doctrine will or will not be raised in an audit.

The directive implements a four-step decision-making framework. Step 1 consists of a set of factors for use in evaluating "whether the circumstances in the case are those under which application of the economic substance doctrine to a transaction is likely not appropriate." ${ }^{230}$ Although weight is not assigned to the factors, the Step 1 factors are divided into two categories. The first category consists of 18 factors. Most of the factors are standard red flags for abusive tax avoidance and require the examiner to look for the absence of such items: for example, "Transaction is not promoted/developed/administered by tax department or outside advisors" and "Transaction does not involve a tax-indifferent counter-party that recognizes substantial income."231 Some of the factors restate portions of the codified statute and require the examiner to look for their presence: for example, "Transaction has credible business purpose apart from federal tax benefits." ${ }^{232}$ Evaluation is also required of whether a " $[\mathrm{t}]$ ransaction that generates targeted tax incentives is, in form and substance, consistent with Congressional intent in providing the incentives." ${ }^{233}$ This factor is in line with the first component of the relevance provision interpretation advanced throughout this Article, though the LB\&I directive follows the JCT Report version and omits the adverb "clearly." ${ }^{34}$

The second category discussed in Step 1 consists of the four items listed in both the JCT report and 2009 Ways and Means Report as "basic business transactions" that the economic substance doctrine is "not intended to alter." ${ }^{235}$ This mini-angel list is preceded by the warning that "it is likely not appropriate to raise the economic substance doctrine if the transaction being considered is related to the following circumstances." ${ }^{236}$ Importantly, this language creates only a presumption of inapplicability but does not cut off all consideration of the doctrine even as to these items. Similarly, even the absence of multiple problematic factors does not absolutely block further scrutiny under the doctrine. ${ }^{237}$

${ }^{229} \mathrm{Id}$.

${ }^{230} \mathrm{Id}$. Step 1 is integrally related to Step 2; indeed, they are, in substance, arguably a single step. This Article describes the LB\&I directive more formalistically in order to highlight the slight differences between Step 1 and Step 2.

${ }^{231} I d$.

${ }^{232} I d$.

${ }^{233} \mathrm{Id}$.

${ }^{234}$ Id.; JCT REP., supra note 67.

${ }^{235}$ See supra Part III.B.3.

${ }^{236}$ Memorandum from Heather Maloy, supra note 222.

${ }^{237}$ Id. ("If some of the factors . . apply to the transaction, and an examiner continues to believe that the application of the doctrine is appropriate, the examiner should continue to analyze the transaction using the guidance set forth in Steps 2-4."). 
This flexibility is consistent with the language in the history suggesting that facts and circumstances could lead to a conclusion that basic business components of a larger, extended tax avoidance scheme could still fail for lack of economic substance. ${ }^{238}$ Thus, Step 1 stakes a claim for broad use of discretion during the audit proceedings, a claim that is fully supported by the relevance provision, as it is interpreted in this Article. At the same time, the LB\&I directive is not asserting that ordinary business transactions-if truly ordinary-are subject to the doctrine. This is made clear by the words of caution and by the supervisor involvement required at later steps. ${ }^{239}$ The preservation of flexibility simply reflects an understanding that tomorrow's tax shelter could be constructed using bits of basic business transactions.

Step 2 of the directive contains a list of facts and circumstances "tend[ing] to show that the application of the economic substance doctrine may be appropriate."240 The difference in wording between Step 1 ("likely not appropriate") and Step 2 ("may be appropriate") is striking and operates again in the direction of restraint. There is no Step 2 counterpart to the Step 1 second set of basic business transaction factors - no demon list. Instead, the factors are the inverse of the Step 1 factors. ${ }^{241}$ The only factor not repeated in Step 2 is the one requiring an evaluation that the transaction "is, in form and substance, consistent with Congressional intent in providing the incentives." 242

If an examiner emerges from Steps 1 and 2 with a belief "that the application of the economic substance doctrine may be appropriate," Step 3 contains a more pointed series of seven inquiries. ${ }^{243}$ In general, if the examiner answers any of the seven questions in the affirmative, then the examiner must receive approval from his or her manager before proceeding. ${ }^{244}$ Three of the inquiries look more deeply at whether the transaction is instead blessed by a specific statute or group of statutes. ${ }^{245}$ Again, this is consistent with the proposed interpretation of the relevance provision. One question requires greater scrutiny into whether judicial or administrative "precedent" has permitted the transaction (or one substantially similar) either by rejecting application of the economic substance doctrine or by upholding it without mention of the doc-

${ }^{238} I d$.

${ }^{239} I d$.

${ }^{240} \mathrm{Id}$.

${ }^{241}$ For example, "Transaction is promoted/developed/administered by tax department or outside advisors," "Transaction involves a tax-indifferent counter-party that recognizes substantial income," and "Transaction has no credible business purpose apart from federal tax benefits." Id.

${ }^{242}$ See id.

${ }^{243}$ See id.

${ }^{244} I d$.

${ }^{245}$ The inquiries are as follows: (a) "Is the transaction a statutory or regulatory election?"; (b) "Is the transaction subject to a detailed statutory or regulatory scheme?"; and (c) "Does the transaction involve tax credits (e.g., low income housing credit, alternative energy credits) that are designed by Congress to encourage certain transactions that would not be undertaken but for the credits?" Id.

Tax Lawyer, Vol. 66 , No. 3 
trine. ${ }^{246}$ Three final questions require consideration of whether some other approach might be preferable-a general substance-over-form approach, for example. ${ }^{247}$

After Step 3 is completed, Step 4 requires another round of supervisory scrutiny. The examiner, "in consultation with his or her manager and territory manager, should describe for the appropriate DFO [director, field operations ${ }^{248}$ ] in writing how the analysis described in the guidance above was completed." 249 The director of field operations must not only review the material but also consult with the Chief Counsel's office before a decision is made. ${ }^{250}$ Then, if the director decides to go forward, he or she "shall provide the taxpayer an opportunity to explain their position, either in writing or in person (at the DFO's discretion), addressing whether the doctrine should be applied to a particular transaction. Once the DFO has made a final decision, that decision should be conveyed to the examiner in writing." 251 The opportunity for taxpayer input at this stage in the process again highlights the Service's restraint in utilizing the codified doctrine, and it also reveals an understanding of the political fallout that would arise if field agents began to apply the doctrine indiscriminately.

The LB\&I directive does not contain much guidance, however, about how to find the boundaries of a "transaction." It provides:

[W] hen a transaction involves a series of interconnecred steps with a common objective, the term 'transaction' refers to all of the steps taken together. However, in certain circumstances, it may be appropriate to apply this guid-

${ }^{246} I d$. ("Does precedent exist (judicial or administrative) that either rejects the application of the economic substance doctrine to the type of transaction or a substantially similar transaction or upholds the transaction and makes no reference to the doctrine when considering the transaction?")

${ }^{247}$ These inquiries are as follows: (a) "Does another judicial doctrine (e.g., substance over form or step transaction) more appropriately address the noncompliance that is being examined? . . . To determine whether another judicial doctrine is more appropriate to challenge a transaction, an examiner should seek the advice of the examiner's manager in consultation with local counsel"; (b) "Does recharacterizing a transaction (e.g., recharacterizing debt as equity, recharacterizing someone as an agent of another, recharacterizing a partnership interest as another kind of interest, or recharacterizing a collection of financial products as another kind of interest) more appropriately address the noncompliance that is being examined? If so, recharacterization should be applied and not the economic substance doctrine. To determine whether recharacterization is more appropriate to challenge a transaction" seek management advice; and (c) "In considering all the arguments available to challenge a claimed tax result, is the application of the doctrine among the strongest arguments available? If not, then the application of the doctrine should not be pursued without specific approval." Id.

${ }^{248}$ See Large Business \& International Organization Chart, IRS (Dec. 11, 2012), http://www. irs.gov/pub/irs-utl/lbiorgchart.pdf.

${ }^{249}$ IRS Issues LB\&II Directive on Codified Economic Substance Doctrine and Penalties, 2011 Tax Notes Today 137-17 (July 18, 2011).

${ }^{250} \mathrm{Id}$.

${ }^{251} I d$.

Tax Lawyer, Vol. 66, №. 3 
ance separately to one or more steps that are included within a series of arguably interconnected steps. ${ }^{252}$

If an examiner wants to divide a common transaction into smaller steps, the examiner "is required to seek guidance from their manager and consult with their local counsel before doing so."253

The LB\&I directive was effectively extended to all Service field operations through a notice issued on April 2, 2012, by the Service's Office of Chief Counsel (Counsel Notice). ${ }^{254}$ The Counsel Notice also specified that the LB\&I framework governs when the Service provides advice to the Department of Justice (DOJ) in any tax litigation conducted by the DOJ. ${ }^{255}$ The Notice is aimed at national coordination and consistency in the way the Service raises the economic substance doctrine on audit or litigation or through administrative guidance. The Notice states that the procedures are to be followed " $[t]$ o ensure that the common law ... and the codified economic substance doctrine and related penalties are only raised in appropriate cases."256 The Notice expressly provides that it is not creating new taxpayer rights. ${ }^{257}$

As to the audit process, the Notice directs that Counsel should provide assistance regarding the economic substance doctrine "upon request by the Service during the ordinary course of an examination, including examinations of claims for refund and administrative adjustment requests." 258 The content of any advice should "consider the factors" of the LB\&I directives. 259 Coordination nationally is required as part of any Counsel review of a proposed tax deficiency. The Counsel Notice imposes a higher procedural standard and national coordination before the doctrine is raised by the Service as a "new issue" in Tax Court or in the advice it renders the DOJ as it conducts tax litigation in the other federal courts. ${ }^{260}$ Finally, the Counsel Notice pro-

${ }^{252} I d$.

${ }^{253} I d$.

${ }^{254}$ C.C.N. 2012-008 (Apr. 3, 2012); see also I.R.C. $\$ 7803$ (b) (describing duties of the Chief Counsel, including to be legal advisor to the Commissioner).

${ }^{255}$ C.C.N. 2012-008 (Apr. 3, 2012).

${ }^{256} \mathrm{Id}$.

${ }^{257}$ Id. ("The procedures in this notice do not create any substantive or procedural rights for taxpayers, and the failure to follow any of these procedures in whole, or in part, does not invalidate any otherwise valid notice of deficiency or other Service action.").

${ }^{258}$ Id. For an overview of the audit process, including internal appeals, see RICHARDsON ET AL., supra note 7, at 93-134.

${ }^{259}$ The Notice also requires that if a favorable private letter ruling exists as to the transaction being tested, then the letter ruling must be revoked prior to adjustment under the doctrine, even if the private letter ruling did not address the economic substance doctrine. A letter ruling is binding as to the parties to the ruling, but only to the extent the facts are as provided by the taxpayer in the ruling request and subject to the potential future revocation of the ruling. Although redacted private letter rulings are publicly available, they are not to be relied upon by anyone but the party to the ruling. See Richardson et AL., supra note 7.

${ }^{260} \mathrm{As}$ was the case with the examination-related guidance, if an action is supported by favorable private letter rulings or determination letters, those must be revoked before the doctrine is raised as a new issue. C.C.N. 2012-008 (Apr. 3, 2012). 
vides that administrative pronouncements are to be consistent with the statute and previous guidance, including the LB\&I directive.

\section{The Tax Agencies' Compliance}

The actions of the Treasury and the Service to date are fully consistent with the text, purpose, and history of the doctrine. If anything, they err on the side of caution. ${ }^{261}$ The Service has substantial discretion and powers in conducting audits and litigation. ${ }^{262}$ As argued above, the relevance provision does not so much add an additional constraint on these functions as suggest a course for prudential use of the doctrine. Because of the doctrine's association with the highly politicized health care legislation, circumspection may be especially critical. With the passage of time, or with the emergence of new styles of abusive transactions, the Treasury and the Service may shift course and provide interpretive guidance on the doctrine and on the relevance provision.

\section{B. Narrow Constraint on Administrative Interpretation}

The preceding Subpart suggested that the relevance provision has little direct impact on the tax agencies so long as the tax agencies continue on their present course of avoiding the issuance of regulations. This Subpart considers the effects should the Treasury and the Service change their policy and issue regulations purportedly entitled to strong judicial deference. ${ }^{263}$ This Subpart outlines the path to obtaining such deference. This Subpart then considers how three hypothetical regulation types would fare. For simplicity, it is assumed that the hypothetical regulations meet formal, procedural criteria for

\footnotetext{
${ }^{261}$ Lee Sheppard has argued that the LB\&I directive is so considerate of taxpayers that it amounts to a repeal of the statute. Sheppard, supra note 224 , at 76.

${ }^{262}$ It is beyond the scope of this Article to discuss more fully the audit and litigation functions except to say that they are broad. See Brudney \& Ditslear, supra note 20, at 1297 (discussing tax-specific canon "favoring broad tax coverage or broad IRS authority").

Multiple procedural limits, of course, apply to those functions. The contours of more equitable constraints-such as a duty of consistency-are less clear. See Steve R. Johnson, An IRS Duty of Consistency: The Failure of Common Law Making and a Proposed Legislative Solution, 77 Tenn. L. Rev. 563, 566-67 (2010); Christopher Pietruszkiewicz, Does the Internal Revenue Service Have A Duty to Treat Similarly Situated Taxpayers Similarly?, 74 U. CINN. L. REv. 531, 535 (2005); Lawrence Zelenak, Should Courts Require the Internal Revenue Service to Be Consistent?, 40 TAX L. Rev. 411, 417 (1985).

${ }^{263}$ Chevron U.S.A., Inc. v. Natural Res. Def. Council, 467 U.S. 837, 865 (1984).
} 
obtaining strong deference ${ }^{264}$ and that they are not issued during the course of litigation or in response to a court decision. ${ }^{265}$

\section{Ambiguity, Reasonableness, and the Relevance Provision}

The Supreme Court's Cheuron decision provides what seems a straightforward formula for determining whether an agency's interpretation of a statute should receive strong judicial deference. ${ }^{266}$ The vast case law and scholarship on the Chevron two-step have shown, however, that the formula is far from easy to apply ${ }^{267} \mathrm{~A}$ detailed discussion of Chevron's nuances and complexities is beyond the scope of this Article. In general, however, under the formulation of Chevron, the first step requires a determination that the statute contains a gap that the agency issuing the regulation has the authority to fill. ${ }^{268}$ Ambiguity in the text is generally presumed to indicate the existence of such a gap, but there is no clear guidance as to how to determine whether a delegating ambiguity exists. ${ }^{269}$ If it is decided that the statute delegates gap-filling authority, the second Cheuron step requires deference to the agency's interpretation so long as it is reasonable. ${ }^{270}$

Ambiguity and reasonableness are somewhat malleable in that a judge's underlying approach to statutory interpretation may strongly influence the

${ }^{264}$ See supra note 219 (discussing United States v. Mead Corp., 533 U.S. 218 (2001); Mayo Found. for Educ. \& Research v. United States, 131 S. Ct. 704, 714 (2011)); see also In re Quality Stores, Inc., 693 F.2d 605, 619-20 (6th Cir. 2012) (giving no Chevron deference for revenue ruling); In re Long-Distance Tel. Serv. Fed. Excise Tax Refund Litig., 853 F. Supp. 2d 138, 146 (D.C. Cir. 2012) (prospectively vacating Notice 2006-50 because of failure to meet notice and comment requirements of the Administrative Procedure Act).

${ }^{265}$ See United States v. Home Concrete \& Supply, 132 S. Ct. 1836, 1838 (2012); Nat'l Cable \& Telecomms. Ass'n v. Brand X Internet Serv., 545 U.S. 967, 981-82 (2005); see also Lederman, supra note 15 at 673-74; Gregg Polsky, Can Treasury Overrule the Supreme Court?, 84 B.U. L. Rev. 185, 204 (2004).

${ }^{266}$ Chevron, 467 U.S. at $842-43$.

${ }^{267}$ See authorities cited supra note 15.

${ }^{268}$ See Cheuron, 467 U.S. at 843-44 ("If Congress has explicitly left a gap for the agency to fill, there is an express delegation of authority.").

${ }^{269}$ Id. at 844 ("Sometimes the legislative delegation . . . is implicit."); see also United States v. Home Concrete \& Supply, LLC, 132 S. Ct. 1836, 1843 (2012).

${ }^{270}$ Chevron, 467 U.S. at 844 ("[A] court may not substitute its own construction of a statutory provision for a reasonable interpretation made by the . . . agency.").

In the main text, "reasonableness" indicates substantive reasonableness (i.e., reasonable interpretation of statute). Reasonableness may also incorporate a requirement that the interpretation be accompanied by explanations demonstrating that the position was arrived at through reasoned decision making. See Motor Vehicle Mfrs Ass'n of United States, Inc., v. State Farm Mut. Auto. Ins. Co., 463 U.S. 29, 43 (1983). For discussion of State Farm and its relation to Chevron step two, see Judulang v. Holder, 132 S. Ct. 476, 483 n.7 (2011); Lisa Schultz Bressman, Chevron's Mistake, 58 Duke L.J. 549, 585-86 (2009); Aprill, supra note 22, at 2118-21; Patrick J. Smith, The APA's Arbitrary and Capricious Standard and IRS Regulations, 2012 TAX Notes Today 137-4 (July 17, 2012); Peter L. Strauss, Overseers or "The Deciders"-The Courts in Administrative Law, 75 U. CHI. L. Rev. 815, 826 (2008). This Article will address only substantive reasonableness and assume that the agencies have engaged in "reasoned decision making" and have provided an adequate explanation of the same. 
outcome. The Supreme Court in Chevron directed, "If a court, employing traditional tools of statutory construction, ascertains that Congress had an intention on the precise question at issue, that intention is the law," ${ }^{271}$ and "legislative regulations are given controlling weight unless ... manifestly contrary to the statute." 272 Statutory interpretation thus may play a role at both steps. While as a practical matter most judges will look at legislative history (particularly in tax cases), as has been already noted in this Article, some judges are deeply averse to any use of legislative history. ${ }^{273}$

In the case of future economic substance regulations, a judge willing to consider fully the legislative history discussed above may conclude that Congress left some interpretive gaps for agencies to fill but that this authority was limited by an intention that the agencies not interpret their way into deciding individual transactions in place of courts. As a result, such a judge may be more inclined to find no reason to move to the second Chevron step given a regulation that overstepped the gap.

A judge unwilling to look to legislative history might decide that the relevance provision is ambiguous, that ambiguity equals delegation, and quickly move to the second Cheuron step. ${ }^{274}$ On the other hand, a textualist judge may also be more ready to assert that the relevance provision is not ambiguous. ${ }^{275} \mathrm{~A}$ textualist judge might, for example, start with the view that the plain meaning of the "never been enacted phrase" is that no economic substance

${ }^{271}$ Chevron, 467 U.S. at 843 n.9.

${ }^{272}$ Id. at 844; see also Mashaw, supra note 20, at 830-31 (discussing "traditional tools" in terms of textualist influence on the use of legislative history).

${ }^{273}$ See Brudney \& Ditslear, supra note 20, at 1254, 1291 ("The Court in tax law decisions relies significantly more on both legislative history and language canons-and somewhat more on substantive canons-than it does in labor and employment cases"; but "Justice Scalia has adopted this implacable stance [against using legislative history] in tax law cases as well.").

The recent Supreme Court case of United States v. Home Concrete \& Supply highlighted the divide between Justice Breyer and Justice Scalia on this issue. Home Concrete, 132 S. Ct. at 1836. The case addressed whether a Supreme Court's prior opinion interpreting a tax statute of limitation precluded the Treasury's conflicting interpretation. Id. at 1838. Justice Breyer, writing for a plurality of justices, explained that the prior Supreme Court opinion, which included an "examination of legislative history," had already determined that Congress had clearly spoken on the issue. Id. at 1844 . As a result, no gap-filling delegation existed that the regulation could fill. Id. Justice Scalia concurred in the result because of "justifiable taxpayer reliance," but he took the plurality to task, emphasizing that "Post-Chevron cases do not 'conclude' that Congress wanted the particular ambiguity resolved by the agency; that is simply the legal effect of ambiguity - a legal effect that should obtain whenever the language is in fact ... ambiguous." Id. at 1847 (Scalia, J., concurring); see also Sunstein, supra note 15 (discussing division between Justice Breyer and Justice Scalia).

${ }^{274}$ See, e.g., United States v. Mead Corp., 533 U.S. 218, 257 (2001) (Scalia, J., dissenting) ("Ambiguity means Congress intended agency discretion. Any resolution of the ambiguity by the administering agency that is authoritative ... must be accepted ... if it is reasonable.").

${ }^{275}$ See Scalia, supra note 15, at 521 ("One who finds more often (as I do) that the meaning of a statute is apparent from its text and from its relationship with other laws, thereby finds less often that the triggering requirement for Cheuron deference exists."). 
regulations (other than on foreign taxes) ${ }^{276}$ are candidates for strong deference because, prior to enactment, there was no statutory provision to interpret. As already discussed above, however, this reading is at odds with the general grant of interpretive authority contained in section 7805(a). ${ }^{277}$ To interpret the relevance provision as a blanket restriction on regulations, a judge would further have to conclude that the "never been enacted" language is specific enough to repeal section 7805(a) as to the economic substance doctrine. ${ }^{278}$

Yet an alternative reading of the text could suggest the opposite conclusion - that there is no ambiguity as to regulatory authority because that is not what the provision is about. ${ }^{279}$ The dictionary meanings of the term "relevant" refer more to preliminary connections between the doctrine and a transaction than to ultimate resolution of the decision; thus, the relevance provision could also be read as meaning simply that tax agencies are to continue testing transactions using the same basic criteria they did before enactment. ${ }^{280}$ That the text potentially supports multiple "plain" readings suggests that it is ambiguous.

As with a determination of ambiguity, the extent to which legislative history may be used to establish the reasonableness of an interpretation is unsettled. ${ }^{281}$ In any event, with respect to many potential, future economic substance doctrine regulations, the legislative history would provide only confirmation of an outcome rather than change the outcome. ${ }^{282}$ For example, if the agency issued regulations providing that specific tax credits automatically failed the subjective inquiry of the economic substance doctrine, it would not take a judge willing to look at legislative history to determine that this would

${ }^{276}$ See supra notes $124-32$ and accompanying text.

${ }^{277}$ I.R.C. $\$ 7805$ (a).

${ }^{278}$ See SCAlia \& GARNER, supra note 133, at 279 ("[W] asserted, the implication must be clear enough to overcome the presumption against implied repeal.").

${ }^{279} \mathrm{~A}$ third possibility is that a judge could decide that the issue of final relevance is purely factual and thus not open to agency interpretation. See supra note 136 (discussing standard of review problem); see also infra text accompanying notes 294-97 (discussing facts of Mayo). The proximity of tax avoidance to tax crimes may also have an effect pointing toward reservation of discretion to the courts. See Dan Kahan, Is Chevron Relevant to Federal Criminal Law?, 110 Harv. L. Rev. 469 (1996).

${ }^{280}$ See supra text accompanying note 164 .

${ }^{281}$ See supra text accompanying note 20.

${ }^{282}$ See ESKRIDGE, JR, supra note 20. 
be an unreasonable interpretation of the doctrine's scope. ${ }^{283}$ The next Subpart suggests hypothetical regulations as to which the legislative history might be more essential to a determination of reasonableness.

\section{Hypothetical Regulations}

The hypothetical regulations discussed below are intended to draw attention to a narrow constraint the legislative history suggests as to the tax agencies' ability to promulgate Cheuron deference-earning regulations. The limit should only be as strong as is required to ensure that the codified economic substance doctrine develops "in the same manner" as the common law. This Article argues that the relevance provision only prevents the tax agencies from obtaining Cheuron deference for regulations that have the effect of directly deciding ex ante that a specific transaction fails the doctrine. Regulations that define ambiguous terms and that have an indirect effect on a transaction's ability to survive the economic substance doctrine would be entitled to Chevron deference (assuming procedural requirements to obtaining such deference are followed). Of course, nothing prevents the tax agencies from specifying in advance that particular transactions lack economic substance; as to such pronouncements, however, judicial deference should turn on the persuasiveness of the tax agencies' position.

a. Neither Angels Nor Demons. Immediately following codification, several practitioners requested that the tax agencies issue "angel" lists-lists of transactions that the agencies would not attack for lack of economic substance. ${ }^{284}$ The tax agencies have, so far, refused to do so. ${ }^{285}$ Because taxpayers would be unlikely to challenge "angel" list regulations, this section considers the results if the tax agencies were to issue "demon" list regulations. The same

${ }^{283}$ The legislative history would also be of little help as to hypothetical regulations in which the agencies set out the scope of their own authority. For example, assume the agencies issue regulations that interpret the relevance provision as a blanket restriction on the agencies' ability to issue further regulations. Or, alternatively, they promulgate regulations providing that the relevance provision offers no constraints on the agencies' usual interpretive authority. Such regulations, while interesting to contemplate, do not offer testable interpretations of the statute. As to the first possibility, it is unlikely that any taxpayer would want to challenge a "no regulation" regulation, but there is also no clear path for challenging such an interpretation, given the general requirement in tax law of an actual deficiency or refund claim before tax law may be challenged. See I.R.C. $\$ 7421$ (known as "Anti-Injunction Act"); Nat'l Fed'n Indep. Bus. v. Sebelius, 132 S. Ct. 2566, 2582-84 (2012) (decision regarding health care mandate not barred by Anti-Injunction Act). Similarly, an "all-regulations-permitted" regulation does not become meaningful except in the event additional regulations actually are issued and applied in a specific controversy. The test of the more specific regulation would provide the context and means for testing the more general assertion of authority.

${ }^{284}$ See McMahon Jr., supra note 26.

${ }^{285}$ See, e.g., George G. Jones \& Mark A. Luscombe, Tax Strategy: Codification of economic substance: Ready or not, Accounting Today (May 24, 2010), http://www.accountingtoday. com/ato_issues/24_6/tax-strategy-codification-of-economic-substance-ready-or-not-54210-1. heml. 
analysis would apply if courts were instead considering whether to accord strong deference to a regulatory list of angelic transactions.

Creating such regulations would be a relatively easy matter. The Code already contains disclosure requirements for "reportable transactions" and grants specific authority to the tax agencies to identify which transactions are reportable. ${ }^{286}$ Under the Code, a reportable transaction is one that the tax agencies determine has "a potential for tax avoidance or evasion." $287 \mathrm{~A}$ subcategory of reportable transactions known as "listed transactions" has a higher associated penalty for disclosure failures. ${ }^{288}$ "Listed transactions" are those which the tax agencies identify "as a tax avoidance transaction." 289 The tax agencies have issued multiple "listed transaction" notices. ${ }^{290}$ Regulations issued under the codified economic substance doctrine could use listed transaction notices to build "demon" lists. ${ }^{291}$

This Article argues that the relevance provision should prevent such a regulation from being reasonable for purposes of gaining Cheuron deference. That a transaction is also a listed transaction may well persuade a court that it fails economic substance, ${ }^{292}$ but under the proposed interpretation of the relevance provision, the court should retain the judgment call as to whether the transaction ultimately fails the economic substance doctrine. A useful contrast may be drawn through consideration of the Supreme Court's decision in Mayo Foundation for Medical Education \& Research $v$. United States. ${ }^{293}$ At issue was whether a regulation deliberately defining "student" so as to exclude medical residents should be given strong deference. ${ }^{294}$ In a unanimous, eight-justice decision, ${ }^{295}$ the Court held that the statute's term, "student," was ambiguous and that the regulation (issued pursuant to section 7805(a)) was owed

${ }^{286}$ See supra note 39 and accompanying text.

${ }^{287}$ I.R.C. $\$ 6707 \mathrm{~A}(\mathrm{c})(1)$.

${ }^{288}$ I.R.C. $\$ 6707 \mathrm{~A}(\mathrm{~b})$.

${ }^{289}$ I.R.C. $\$ 6707 \mathrm{~A}(\mathrm{c})(2)$.

${ }^{290}$ See supra note 39 and accompanying text.

${ }^{291}$ This Subpart is assuming that proper formalities are observed. See supra note 219 (discussing Mead and Mayo). A regulation simply specifying that any listed transaction entered into after the effective date of the codified economic substance doctrine automatically fails the procedural requirements of the Administrative Procedure Act, including the opportunity for notice and comment as to both the listed transactions notice and the economic substance regulation. See In re Quality Stores, Inc., 693 F.2d 605, 619-20 (6th Cir. 2012) (no deference for position that supplemental unemployment benefits constituted wages for purposes of FICA because no promulgared regulations). With thanks to Kristin Hickman for this observation.

${ }^{292}$ See supra note 219 (listing articles discussing Skidmore deference).

${ }^{293}$ Compare Mayo Found. for Med. Educ. \& Research v. United States, 131 S. Ct. 704 (2011), with In re Quality Stores, 693 F.2d at 619-20 (holding that the position that supplemental unemployment benefits constituted wages for purposes of FICA does not deserve deference because the regulations were not promulgated).

${ }^{294}$ Mayo, 131 S. Ct. at 709-10. The rule was amended in December 2004 and made it clear that medical residents could not rely on a student exception to collection of the Social Security tax. Id. at 709 .

${ }^{295}$ Id. at 708 (8-0 decision; Justice Kagan did not participate). 
Chevron deference as a reasonable interpretation of the term. ${ }^{296}$ As a result, the legal question of whether a medical resident is a student has been settled; future litigation will be about facts-whether someone is a medical resident. This Article argues that attempts to define terms such as "relevant" or "transaction" in a way that would directly remove the ultimate relevance decision from a court's discretion would be unreasonable interpretations of the statute.

The legislative history support for this limit was discussed in Part III (of course, a judge willing to use that history may have been convinced that the decision regarding ultimate relevance had not been delegated in any case. ${ }^{297}$ The case for a textualist judge reaching the conclusion that "demon" lists are unreasonable is less robust. If such a judge is willing to see ambiguity, the same judge is also likely to be more willing to defer to regulations. One potential path would require recognition of a conflict between the "never been enacted" language and section 7805(a)'s general delegation of interpretive authority. ${ }^{298}$ If such a conflict were recognized, ${ }^{299}$ a textualist judge might then reconcile the provisions by determining that courts retain discretion over ultimate relevance. ${ }^{300} \mathrm{~A}$ textualist judge might also reason that the reportable transaction provisions indicate that Congress knows how to grant authority for specific listmaking activities, yet Congress did not provide such authority in the case of the economic substance doctrine. ${ }^{301}$ Willingness to look at legislative history could, however, prove crucial to the outcome of this hypothetical given the high bar required for a determination that a regulation is unreasonable.

b. Seeing Red. The second hypothetical regulation is derived from internal guidance that has already been issued. As was discussed above, internal guidance requires field agents to review a listing of multiple factors when deciding whether to pursue an economic substance doctrine analysis. ${ }^{302}$ Now consider hypothetical regulations listing red flags and specifying that if a transaction exhibits three or more of the red flags, then the transaction auto-

${ }^{296}$ Id. at 711,714 .

${ }^{297}$ See supra Part IV.B.1.

${ }^{298}$ See supra Part IV.B.1.

${ }^{299}$ See supra Part IV.B. 1 (discussing possible reading that viewed relevance provision as being only about preliminary and not final relevance). Another possibility that would lead to the same outcome-no strong deference for "demon" list regulations-would be if a textualist judge determined that the issue of ultimate relevance was a purely factual determination not amenable to interpretive regulations in the first place. See supra note 136 (discussing standard of review issue).

${ }^{300}$ See SCALIA \& GarNer, supra note 133, at 180 ("The provisions of a text should be interpreted in a way that renders them compatible, not contradictory.").

${ }^{301}$ See supra notes 39, 286-90 and accompanying text discussing a "reportable" transactions regime.

${ }^{302}$ See discussion supra note 230 . 
matically fails the economic substance doctrine. ${ }^{303}$ As with the hypothetical list of "demons," this type of regulation removes the final legal determination from the court; under the proposed interpretation of the relevance provision, such regulations should not be considered reasonable. The reasoning is the same as that applied to the "demon" list regulations, but such a "red flag" regulation would present an even closer case because a red flag regulation would be generally applicable across transactions rather than narrowly tailored to strike down a specific transaction.

If, alternatively, a red flag regulation were altered so it contained room for judicial discretion, then such a regulation-if properly issued-should be entitled to strong deference. For example, a provision could be added specifying that any resulting failure of the economic substance doctrine could be rebutted by a showing that the transaction as structured is clearly consistent with congressionally intended tax benefits. Chevron deference would be available in such a case.

c. So Happy Together. The final hypothetical regulation brings back the solar panel credit hypothetical discussed above and used to highlight the importance of specifying the "transaction." ${ }^{304}$ As David Hariton has explained, how the "transaction" is framed can be outcome determinative. ${ }^{305}$ Assume that the tax agencies issue regulations defining "transaction" that rely on various indicia of interconnectedness such as time proximity, commonality of parties, cash flow tracing rules, or something similar. Next assume that this definition would have caused the "transaction" to include not only the installation of the solar panels, but also all of the other bits that generated even larger tax savings. Such a regulation, which defines only a smaller portion of the doctrine and does so in a generally applicable matter, should get Chevron deference. Under the proposed reading of the relevance provision, this hypothetical regulation does not unreasonably intrude into the court's oversight of the ultimate relevance determination because it is only indirectly outcome determinative.

The same result would apply to other economic substance regulations containing definitions or guidance that similarly indirectly affect outcomes. For example, regulations could be issued setting parameters for measuring pretax profit and for determining when such profit would be "substantial" in relation to the expected tax benefits. ${ }^{306} \mathrm{~A}$ handful of additional ambiguous terms and phrases appear in the codified economic substance doctrine, including "changes in a meaningful way" and "substantial purpose." ${ }^{07}$ Regulations providing definitions of or examples illustrating such phrases could be issued that

${ }^{303}$ Multiple regulations contain facts and circumstances tests, which often list a variety of factors. See, e.g., Reg. $\$ 1.183-2$ (b). The hypothetical departs from this general type of test in including a bright line.

${ }^{304}$ See supra note 140 (discussing use of solar panel credit hypotheticals).

${ }^{305}$ Hariton, Frame Game, supra note 2.

${ }^{306}$ I.R.C. $\$ 7701(\mathrm{o})(2)(\mathrm{A})$.

${ }^{307}$ I.R.C. $\$ 7701(\mathrm{o})(1)$. 
would provide substantial guidance to taxpayers and be entitled to Chevron deference in the judicial system.

\section{Conclusion}

This Article began with a qualitative review of the congressional materials generated in the years the economic substance doctrine was being considered in Congress. The congressional materials suggest approval for a purposive reading of the tax provisions claimed to produce a transaction's tax benefits when agencies and courts are determining whether those benefits are protected from the economic substance doctrine. The congressional materials reveals trust that the tax agencies will continue to exercise sound judgment in raising the doctrine on audit and in litigation and trust in the judicial system's ability to determine the fate of specific tax-avoidance transactions. Judicial discretion as to the ultimate relevance of the doctrine also implies, however, narrow limits on the agencies' ability to bind the court's decision through rulemaking. Judicial oversight over ultimate relevance will undoubtedly influence the agencies in their selection of transactions for audit and litigation. Under the proposed reading of the relevance provision, the relevance games will continue in roughly the same manner as before codification-with the economic substance doctrine arena reserved for transactions meriting the scrutiny. 
Tax Lawyer, Vol. 66, No. 3 